\title{
ODRAZ DOBOVEJ MEŠTIANSKEJ MÓDY NA KOŠICKÝCH NÁLEZOCH KACHLÍC Z 15.-16. STOROČIA
}

\author{
LUCIA LUŠTÍKOVÁ - RASTISLAV RUSNÁK
}

\begin{abstract}
Abstrakt: Príspevok spracováva nevel'ký súbor kachlíc a foriem na kachlice z Košíc cez optiku dobovej módy, ktorá je na nich zobrazená. Žánrovej pestrosti motívov súboru kachlových výrobkov je nadradený hlavný predmet záujmu a tým sú odevy zobrazených postáv. Na určenie jednotlivých typov oblečenia a ich chronologické zaradenie vždy slúžil iba primárny prameň, teda samotný nález. Dôvodom je, samozrejme, aj to, že iba minimum nálezov má identifikovanú ikonografickú predlohu. To ale nebránilo procesu rozkrývania typologickej škály odevov, ktoré nám umožnili preklenút časový rámec približne sto rokov, od polovice 15. do polovice 16. storočia. Aj ked' kachlice predstavujú skôr okrajový prameñ poznania pre skúmanie dobových foriem obliekania, dokázali poskytnút' pestrý a autentický doklad o neskorogotickej a ranorenesančnej móde.
\end{abstract}

Kl'účové slová: Košice - kachlice - móda-gotika-renesancia.

The Reflection of Period Fashion of the Burgher Classes in the Finds of Tiles from Košice from the 15th-16th Centuries

\begin{abstract}
This article presents a small series of tiles and moulds from Košice, from the perspective of period fashion depicted on them. The main subject of interest, the clothing of the represented figures, is supplemented with the genre variety of motifs on the tiles. In the past, only primary sources (finds) were used for the determination of the individual types of clothing and their chronological classification. One of the reasons is that only a small number of finds have iconographic models that can be identified. However, this did not obstruct the process of the disclosing of the typological spectrum of garments that enabled the focus on the period of approximately a hundred years, from the mid-15th century until the mid-16th century. Although tiles represent a marginal source of information for the study of the period forms of clothing, they provide rich and authentic evidence of the late-Gothic and early-renaissance fashion.
\end{abstract}

Key words: Košice - tiles - fashion - Gothic-renaissance.

Ak by sme mali zdokumentovat' formy odievania v neskorom stredoveku a ranej renesancii, tak okrem obmedzeného počtu dodnes zachovaných odevov pravdepodobne siahneme po bohatom fonde rôznych vyobrazení, ktoré nám sprostredkúvajú najmä mal'ované i plastické súčasti gotických oltárov, portrétne obrazy, nástenné mal'by a od rozšírenia kníhtlače i početné grafické listy. V porovnaní s tým predstavujú artefakty dobových kachlíc s figurálnymi motívmi skôr okrajový prameň poznania. Dôvodom sú najmä hendikepy vyplývajúce z technologických a farebných obmedzení, pre ktoré nebolo možné dostatočne verne a do detailov vyobrazit’ námet. Napriek tomu nie je dôvod pochybovat' o tom, že kachliarske remeslo, aj ked' vedomé si spomenutých obmedzení, nevzdávalo svoju snahu byt' dôstojnou súčastou života vyššej society a na jej meniace sa nároky a požiadavky reagovalo s rovnakým citom ako umelecké odvetvia.

Pokúsime sa to doložit' na kolekcii kachlíc a foriem na kachlice, pozostávajúcej z celých exemplárov i menších fragmentov. Ide o rôznorodý súbor, získaný z archeologických výskumov. ${ }^{1}$ Väčšia čast' nálezov už bola v nejakej forme publikovaná (Rusnák 2009; 2013; 2014), nikdy však $\mathrm{v}$ tomto kontexte. To, čo nálezy spája, je ústredný figurálny námet, pričom motívy sa rôznia od náboženských cez žánrové až k portrétnym. Rôznorodost' motívov je druhoradá, ked’že zjednocujúcim rámcom a predmetom záujmu sú pre nás odevy zobrazených postáv. Všímat'si ich cez optiku dobovej módy znamená preklenút' časový rámec približne sto rokov, od polovice 15. do polovice 16. storočia. Nemožno to nazvat' metódou, ked’že občasné prežívanie staršej ikonografie i v dlhšie zmenených podmienkach je na kachliciach doložené viackrát (Loskotová-Menoušková-Pavlík-Vitanovský 2008, 157, 158).

1 Všetky nálezy pochádzajú z archeologických výskumov v historickom jadre mesta realizovaných AÚ SAV - OVVS Košice, najmä v posledných desiatich rokoch. 
Ked’že vieme, že ikonografia námetov je častokrát prevzatá z rôznych dobových grafických predlôh, nie je možné vyzdvihovat’ regionálnu či sociálnu výlučnost’ zobrazovaných odevov. Je to skôr doklad, že meštianstvo v našom prostredí prijalo medzinárodnú dobovú módu za svoju, a preto zobrazované výjavy pre nás nestrácajú na autentickosti. Na určenie jednotlivých typov oblečenia a ich chronologické zaradenie nám vždy slúžil iba primárny prameň, teda samotný nález. Nemožno skrývat', že jedným z dôvodov je i fakt, že vo veci identifikácie ikonografických predlôh sme stále ešte o krok pozadu. V posudzovanom súbore nálezov sú zatial' iba tri fragmenty foriem, ktorých grafické predlohy poznáme. Dve z nich už dávnejšie identifikoval J. Chovanec pri analýze nálezov kachlíc z pece palatína Imricha Perényiho na hrade Parič v Trebišove (2005; 2005a), jednu sa podarilo identifikovat’ pri spracovávaní tohto príspevku. Z dávnejšie známych ide o motív korunovanej Madony s diet'atom (obr. 3; kat. č. 2), ktorej vel'mi verné predlohy nachádzame v grafikách Majstra E. S. a Ishraela van Meckenema (Chovanec 2005, 28) a motív sv. Krištofa (kat. č. 4), ktorého relatívne blízku analógiu možno vidiet’ v drobnej grafike Majstra H. S. (Chovanec 2005, 31). Novoobjaveným je žánrový motív sveta prevráteného naruby, kde si muž a žena vymenia úlohy (obr. 1; Geisberg 1909, T 67; obr. 2; kat. č. 1). Nálezy košických foriem a trebišovských kachlíc naznačujú možnú genetickú spätost' dielne a výrobku. Takýto predpoklad podporujú i d’alšie indície. Z Košíc, z Mäsiarskej 57/A, pochádza kachlica s motívom snúbeneckého páru (kat. č. 5). S identickou kachlicou sa možno stretnút' i v súbore z hradu Parič (Chovanec 2005, 34, obr. 42), i z hradu Korolevo (UA), ktorý bol tiež súčast'ou Perényovského panstva (Prochnenko-Mojzes-Žilenko 2012, 236). Pôvod trebišovského súboru kachlíc sa hl’adal v Košiciach aj v súvislosti s nálezom kachlice s anjelom držiacim štít so štylizovaným erbom Košíc (Chovanec 2005, 38, 39). V príspevku sa preto k tejto kolekcii na viacerých miestach obraciame, najmä ak nám celistvé exempláre kachlíc z Pariča pomáhajú preklenút' nedostatky spôsobené fragmentárnost'ou košických nálezov. Z Košíc evidujeme ešte jednu kachlicu so známou grafickou predlohou. Ide o trochu menej remeselne zvládnuté vyobrazenie Ferdinanda I. Habsburského z Kováčskej 37, no napriek tomu možno jeho predlohu bezpečne identifikovat' s portrétnou grafikou Erhardta Schöna (Šimčík 2013, 227; tab. I.-9).

\section{Katalóg nálezov}

Kat. č. 1 - Košice, Dominikánske námestie 11, muž a žena, svetský žánrový motív, svet obrátený naruby (obr. 2). Fragment hlinenej formy, režný, hnedočervenej farby, reliéfna čast' pokrytá svetlou engóbou. Rozmery: $20 \times$ ?(19) × 3,5 cm. ${ }^{2}$ Lit.: Rusnák 2013, 23.

Výjav zobrazuje dvojicu, muža a ženu, a patrí do radu odl'ahčených, vtipných vyobrazení ich vzájomného spolunažívania. Muž vykonáva ženskú prácu pod prísnym dohl'adom ženy. Čast' formy s hlavami postáv sa nedochovala. Grafickú predlohu výjavu poznáme, je teda možné k nemu pristúpit' ako k celku, aj ked' v oblečení postáv nachádzame niekol'ko rozdielov. Postava ženy má na sebe dlhé košel'ovité šaty vol'ného strihu, niekedy pomenované i ako sukňa. Pri krku sú nariasené do oválneho výstrihu s lemom. Šaty siahajú po zem, pod prsiami sú stiahnuté opaskom. Rukávy sú vol'né, dlhé. Žena si šaty pridržiava mierne vyhrnuté na kolenách tak, aby odhal’ovali topánky. Tie sú špicaté, siahajúce vyše členka, s uzavretou vnútornou stranou, vonkajšia strana a horná čast' topánky sú členené remienkami. Špica je uzavretá. Muž má na sebe dlhé košel’ovité šaty vol'ného strihu. Pri krku sú jemne nariasené do výstrihu s lemom. Šaty siahajú po zem, v záhyboch vol’ne splývajú. Rukávy sú vol'né, dlhé. Šaty zahal'ujú nohy, trčia len špice uzavretých topánok. Muž sedí na stoličke, v jednej ruke drží vreteno a v druhej rám na priadzu. Žena sedí oproti v kresle a poháňa muža k práci tým, že ho bije palicou s namotaným kúdelom priadze. To ale na nedochovanej časti formy nie je vidiet', musíme si pomôct' grafickou predlohou Majstra Olivovej hory (Meister des Ölbergs; obr. 1; Geisberg 1909, T 67). Vidíme na nej i ženin dvojrohý čepiec so závojom, mužovi vidiet' na pleciach kapucňu, pri krku mu vytŕča spodný odev so stojačikom. Rozdiely v oblečení medzi grafickou predlohou a kachl'ovou formou

2 Údaje uvádzané v zátvorke predstavujú najväčši zachovaný rozmer. 
sú spôsobené najmä ich jednoduchším prevedením na úkor niektorých detailov. Odevy vol’ne splývajú, majú menšie členenie, mužovi chýba opasok, žena má sukňu menej vyhrnutú, takže jej nevidiet' spodné prádlo.

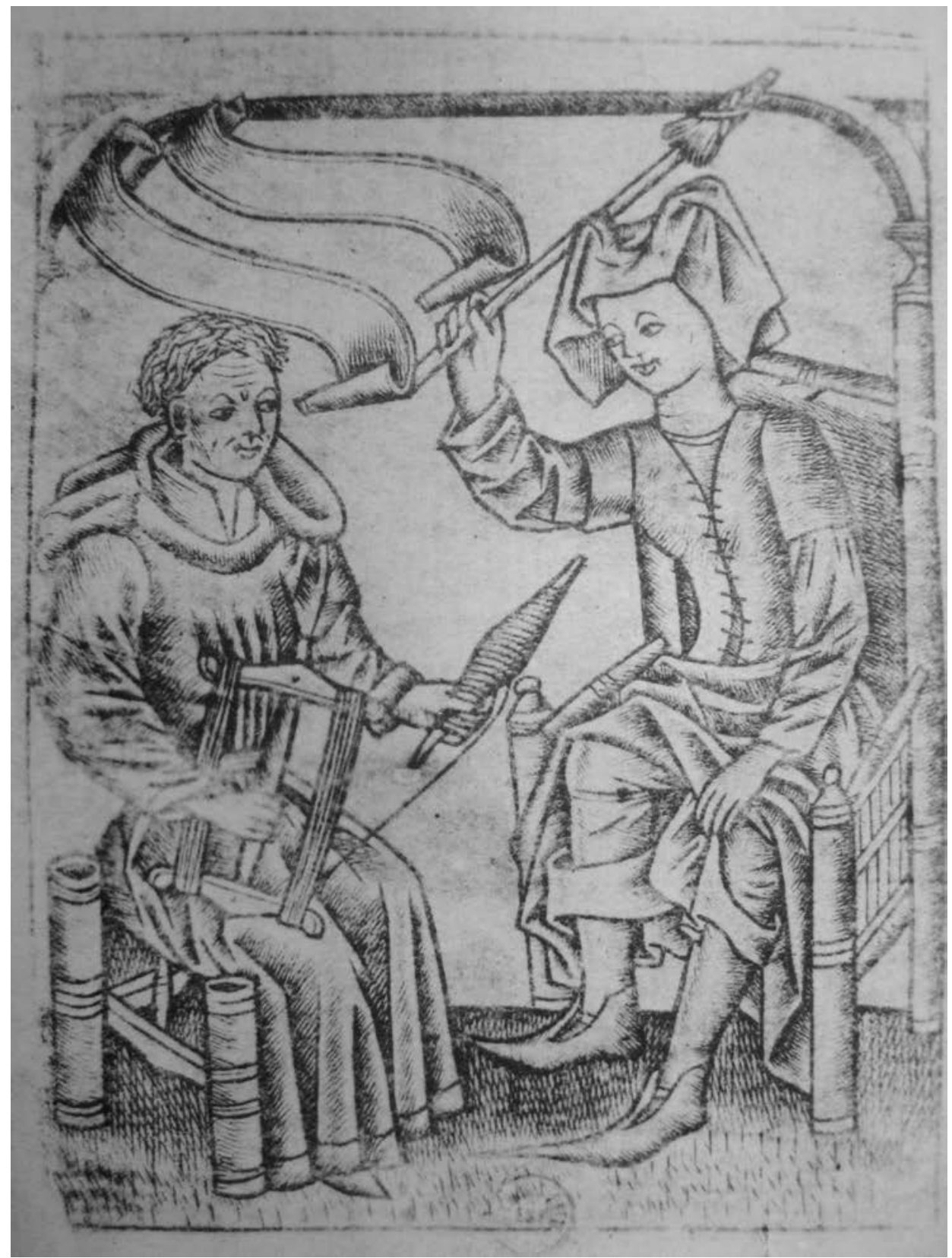

Obr. 1. Majster Olivovej hory (Meister des Ölbergs) - Svet obrátený naruby. Podl’a Geisberg 1909, T 67. Abb. 1. Meister des Ölbergs - Verkehrte Welt. Nach Geisberg 1909, T 67. 
Kat. č. 2 - Košice, Dominikánske námestie 11, Madona s diet'at'om (obr. 3). Fragment hlinenej formy, režný, červenohnedej farby, reliéfna čast' pokrytá svetlou engóbou. Rozmery: ?(20) × ?(25) × 3,5 cm. Lit.: Rusnák 2013, 22.

Postava Madony má vol'né šaty, nariasené do okrúhleho výstrihu s lemom. Siahajú až k zemi, pod prsiami sú stiahnuté opaskom. Na šatách má plášt'. Ten je vol'ný, nariasený a upevnený na ramenách dvojitou šnúrou a párovými sponami. Siaha po zem a je po celom obvode lemovaný. Lem mohol byt' vytvorený stuhou s našívanými perlami, prípadne kožušinou. Spod rúcha trčí uzavretá špicatá topánka. Mária má vol'ne rozpustené vlasy siahajúce až po pás a na hlave korunu. V pravej ruke drží žezlo, v l'avej nahého Ježiška.

Kat. č. 3 - Košice, Dominikánske námestie 11, forma na kachlice, sv. Peter (obr. 4). Exemplár hlinenej formy, režný, červenohnedej farby, reliéfna čast' pokrytá svetlou engóbou. Rozmery: $23 \times 36 \times 6,5$ cm. Lit.: Rusnák 2013, 21 .

Odev svätca tvorí košelovitá tunika splývajúca $\mathrm{v}$ záhyboch a siahajúca tesne nad členky. V páse je stiahnutá opaskom vykladaným drahokamami. Rovnako vykladané sú aj manžety tuniky. Cez plecia má prehodený plášt' siahajúci po členky a zopnutý pod bra-

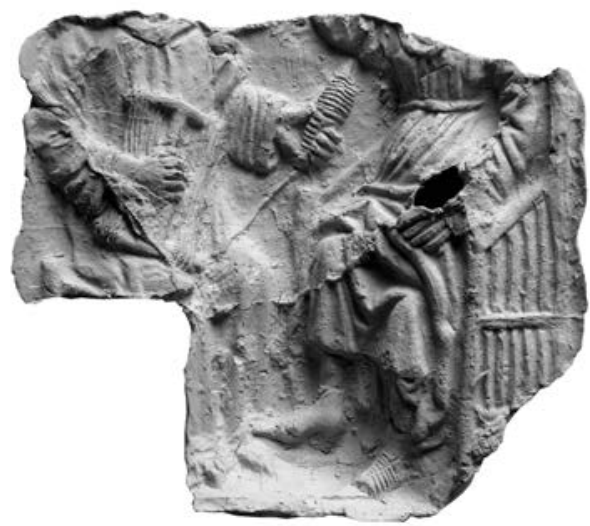

Obr. 2. Košice, Dominikánske nám. 11. Odtlačok formy s výjavom sveta obráteného naruby podl'a grafickej predlohy Majstra Olivovej hory (Meister des Ölbergs). Kat. č. 1. Abb. 2. Košice, Dominikanerplatz. 11. Abdruck einer Kachelform mit Szene der Verkehrten Welt nach einer Grafikvorlage des Meisters des Ölbergs (Meister des Ölbergs). Kat. Nr. 1.

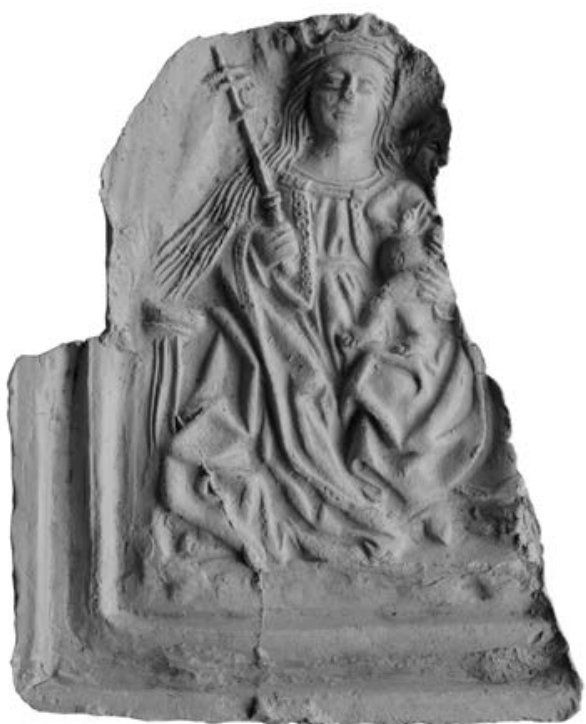

Obr. 3. Košice, Dominikánske nám. 11. Odtlačok formy s výjavom Korunovanej madony s diet'at'om. Kat. č. 2. Abb. 3. Košice, Dominikanerplatz. 11. Abdruck einer Kachelform mit Szene der Gekrönten Jungfrau Maria mit Kind. Kat. Nr. 2.

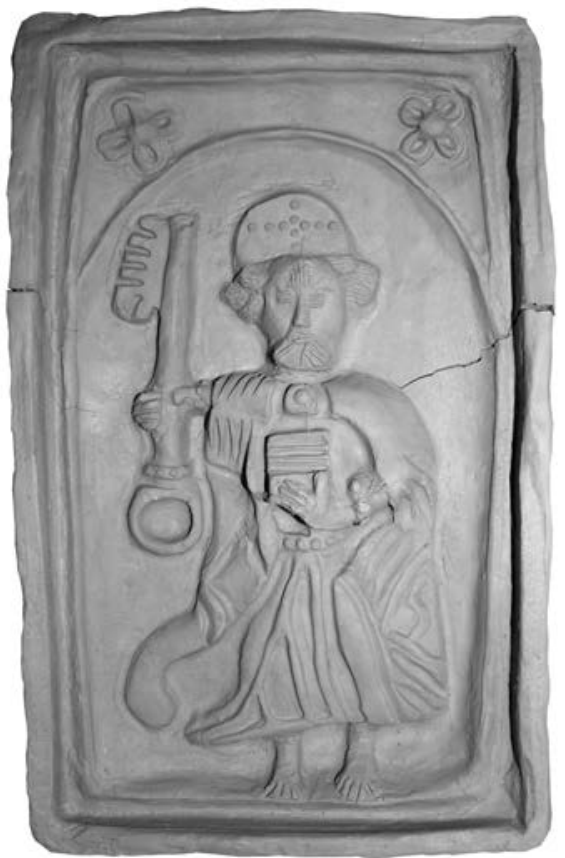

Obr. 4. Košice, Dominikánske nám. 11. Odtlačok formy s výjavom sv. Petra. Kat. č. 3 .

Abb. 4. Košice, Dominikanerplatz. 11. Abdruck einer Kachelform mit Szene des HI. Petrus. Kat. Nr. 3. 
dou ozdobnou sponou. Svätec má na hlave tiaru vykladanú drahokamami, rovnakými ako na opasku a manžetách. Vlasy siahajú k ušiam, účes je upravený, rovnako i brada. Nohy má bosé. Postava je umiestnená vo výklenku, zobrazená s vel'kým kl'účom v jednej a knihou v druhej ruke.

Kat. č. 4 - Košice, Dominikánske námestie 11, forma na kachlice, fragment, sv. Krištof (tab. II:1). Fragment hlinenej formy, režný, červenohnedej farby, reliéfna čast' pokrytá svetlou engóbou. Rozmery: ?(8) × ?(17) × 3,5 cm. Lit.: Rusnák 2013, 23 .

Fragment formy zachytáva len približne štvrtinu výjavu, no jeho ikonografia je identická s dobre zachovanou kachlicou z hradu Parič v Trebišove (Chovanec 2005, 259, F13), čo nám umožňuje zhodnotit' ju ako celok. Odev svätca pozostáva z vol’nej košel'ovitej tuniky siahajúcej pod zadok, riasenej a stiahnutej v páse. Opasok nie je vidiet'. Rukávy sú dlhé, vol’né a rovné. Plášt' je prevesený cez plecia, siaha po kolená a pod krkom je zopnutý ozdobnou sponou. Postava má priliehavé nohavice. Chodidlá sú viditel'né, no obuv nie je konkrétne vizuálne zobrazená. Svätec má zvlnené vlasy siahajúce po ramená, fúzy a bradu. Na pravom ramene nesie Ježiška, v l'avej ruke dlhý konár, ako palicu na podoprenie. Odev Ježiška tvorí vol'ná košel'ovitá tunika siahajúca až k chodidlám s dlhým vol’ným rukávom. V pravom dolnom rohu kachlice je schematicky vyobrazený i pustovník, svietiaci im na cestu.

Kat. č. 5 - Košice, Mäsiarska 57/A, kachlica, žánrový motív - snúbenci (obr. 5). Takmer celý exemplár kachlice, zelená glazúra. Rozmery: 23,5 × $24 \times 11$ cm. Lit.: Rusnák 2014, 348, tab. XIII-3.

Kachlica s dvojicou postáv, muža a ženy, a s motívom zásnub. Muž drží v pravej ruke venček. Žena má dvojdielne šaty z látky bez vzoru, živôtik s vel'kým „V“ výstrihom lemovaným kožušinou alebo stuhami. Vo výstrihu vidiet’ ozdobnú náprsenku alebo predničku z dekoratívnej látky s vel'kým vzorom, vertikálne delenú napoly, lemovanú rovnako ako výstrih. Rukávy sú dlhé, priliehavé, siahajúce po zápästia. Sukňa je riasená, doplnená opaskom. Košel’a má hlboký rovný výstrih. Viditel'ný je z nej iba ozdobný lem tesne nad ukončením výstrihu šiat. Postava má vol’ne rozpustené vlasy, jemne zvlnené, siahajúce do polovice chrbta. Hlavu zdobí čelenka s hviezdou. ${ }^{3}$ Postava muža má na sebe priliehavý kabát z látky bez vzoru s vel'kým

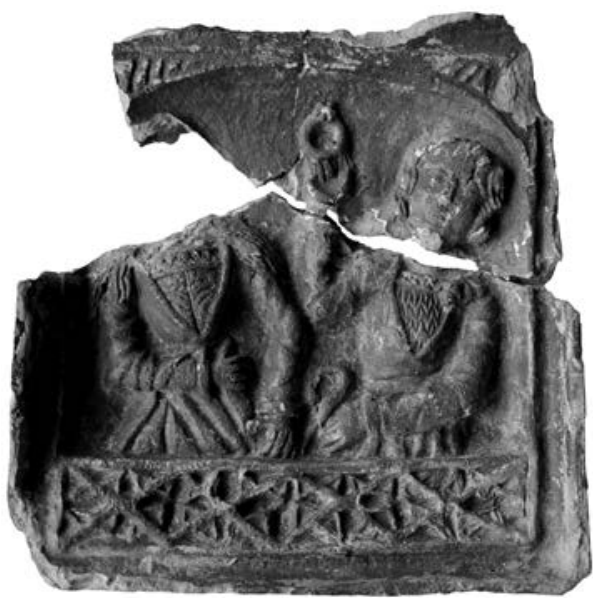

Obr. 5. Košice, Mäsiarska 57/A. Kachlica s motívom snúbeneckého páru. Kat. č. 5. Abb. 5. Košice, Fleischergasse 57/A. Kachel mit Brautpaarmotiv. Kat. Nr. 5.
„V“ výstrihom lemovaným kožušinou alebo stuhami. Vo výstrihu je ozdobný náprsník z dekoratívnej látky s výrazným vzorom, odlišným od vzoru na náprsníku ženy. Rukávy sú dlhé, priliehavé, siahajúce po zápästia. Kabát je $\mathrm{v}$ páse stiahnutý opaskom a siaha pravdepodobne pod zadok, prípadne ku kolenám, ako vol'ne riasený. Z košele je viditel'ný len ozdobný lem tesne nad ukončením výstrihu šiat. Muž nemá pokrývku hlavy, vlasy sú mierne zvlnené a zastrihnuté tak, že lemujú tvár. Architektonické rámovanie výjavu už má tvar vel'mi štylizovanej renesančnej niky, no spodný okraj ešte tvorí prelamované gotické zábradlie.

Kat. č. 6 - Košice, Hlavná 16, fragment kachlice, žánrový motív - snúbenci (obr. 6). Fragment kachlice, zelená glazúra. Rozmery: $?(25,5) \times 24,8 \times ?(12,2) \mathrm{cm}$. Lit.: Rusnák 2009, 106, tab. 80 .

3 Hlava ženy sa na kachlici nezachovala, no poznáme jej podobu z d’alšieho, menšieho fragmentu (Rusnák 2014, Tab. XIII-1) a rovnako i z identickej kachlice z Pariča (Chovanec 1990, 388, obr. 6-1). 
Kachlica s dvojicou postáv, muža a ženy. Postava muža sa zachovala od hlavy po pás a od kolien po chodidlá, postava ženy od pása po chodidlá a pravá ruka. Vrchný odev ženy tvoria šaty, ich členenie od pása nahor sa nezachovalo. Rukávy sú dlhé, vol’né, rozširujúce sa a ukončené širokou manžetou. Sukňa siaha až po zem a spolu s vlečkou je riasená do záhybov a zahal'uje topánky. Žena má vol'ne rozpustené zvlnené vlasy, siahajúce na chrbát. Mužov vrchný odev je vypasovaný kabát $\mathrm{s}, \mathrm{V}$ “ výstrihom s ozdobným šnurovaním. Kabát je v páse pravdepodobne stiahnutý opaskom (prekryté rukou), od pása nadol je rozšírený a v záhyboch siaha tesne pod zadok. Rukávy sú dlhé, rovné. $\mathrm{V}$ časti od ramena po laket' sú zdobené dlhým prestrihom. Ukončené sú manžetami, podobne ako ženské šaty. Spodný odev tvorí košela s oválnym výstrihom siahajúca až ku krku, čím vypíňa „V“výstrih. Muž má priliehavé nohavi-

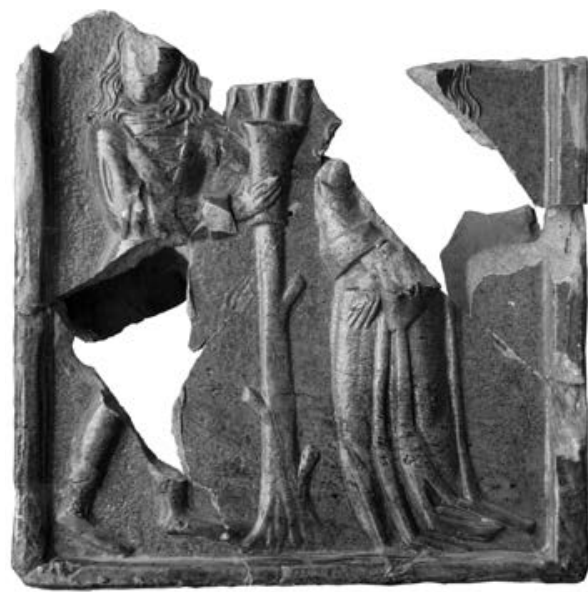

Obr. 6. Košice, Hlavná 16. Kachlica s motívom zasnúbenia. Kat. č. 6.

Abb. 6. Košice, Hauptstraße 16. Kachel mit Verlobungsmotiv. Kat. Nr. 6.

ce. Uzavreté topánky, siahajúce nad členky, sú ukončené manžetou. Rozpustené mierne zvlnené vlasy mu siahajú až po ramená. Muž pravdepodobne drží v ruke pohár v geste, akoby ho podával žene, čím dokresl'uje dojem galantnej scény. Medzi oboma postavami vyrastá strom, ktorý by mohol byt' symbolom vzrastu budúceho štastia a naznačuje tak, že ide o motív zásnub (Loskotová-Menoušková-Pavlík-Vitanovský 2008, 58).

Kat. č. 7 - Košice, Dominikánske námestie 11, fragment formy, žánrový motív, hráč na lutnu, galantná scéna (?) (tab. II:2). Fragment hlinenej formy, režný, červenohnedej farby, reliéfna čast' pokrytá svetlou engóbou. Rozmery: ?(8) × ?(19) × 7 cm. Lit.: Rusnák 2013, 25.

Na výjave bol pravdepodobne pôvodne zobrazený pár. Zachovala sa čast' postavy muža, rameno po laket', čast' trupu a čast' hlavy. Odev tvorí úzky kabát s vel'kým „V“ výstrihom, siahajúcim takmer až po pás, s ozdobným šnurovaním. Vo výstrihu je košel’a. Rukáv je v časti od pleca po laket' balónový, vol'ný. Muž má na hlave bud' jednoduchú čelenku a to, čo vidíme na vrchu hlavy, sú naznačené vlasy, alebo je to nízky klobúčik z dvoch druhov látky. Vlasy vol’ne splývajú po plecia. Hráč na lutnu mohol sprevádzat' postavu v tanci, hráča/ku na iný nástroj, prípadne dvorit' dáme (obr. 7; Strauss 1981, 169).

Kat. č. 8 - Košice, Dominikánske námestie 11, fragment kachlice, portrétny motív s polpostavou neznámeho muža (tab. I:4). Fragment kachlice, zelená glazúra. Rozmery: $?(11,5) \times ?(12,5) \times 6,5 \mathrm{~cm}$. Nepublikované.

Polpostava muža natočeného dol’ava s dvoma rozpoznatel'nými druhmi odevu. Vrchný odev je bohato nariasený pri krku, bez výstrihu (prípadne sa nezachoval), bez zapínania. Rukáv je vol’ný, dlhý, rovného strihu, je však vyhrnutý, čo spôsobuje vol'né nariasenie v časti od lakt’a po zápästie. Riešenie v páse prekrýva ruka (opasok alebo vol'ne splývajúce). Postava má cez plecia prehodený plášt', zopnutý pri krku. Zopnutie nie je zachované (spona/šnúry/gombíky). Muž má pravú ruku preloženú cez spodný okraj renesančnej niky, ktorá rámuje výjav. Zachoval sa z nej len jednoduchý plastický sokel a čast' nezdobenej steny v perspektíve.

Z blízkej lokality, z Dominikánskeho kláštora, pochádza jeden malý fragment rovnakej kachlice, no z inej matrice. Zachovala sa na ňom iba čast' rukáva a dlaň (tab. I:2).

Kat. č. 9 - Košice, Dominikánske námestie 11, fragment kachlice, portrétny (?) motív s polpostavou (?) neznámej ženy (tab. I:1). Fragment kachlice, zelená glazúra. Rozmery: $21 \times ?(11,5) \times ?(6) \mathrm{cm}$. Nepublikované. 


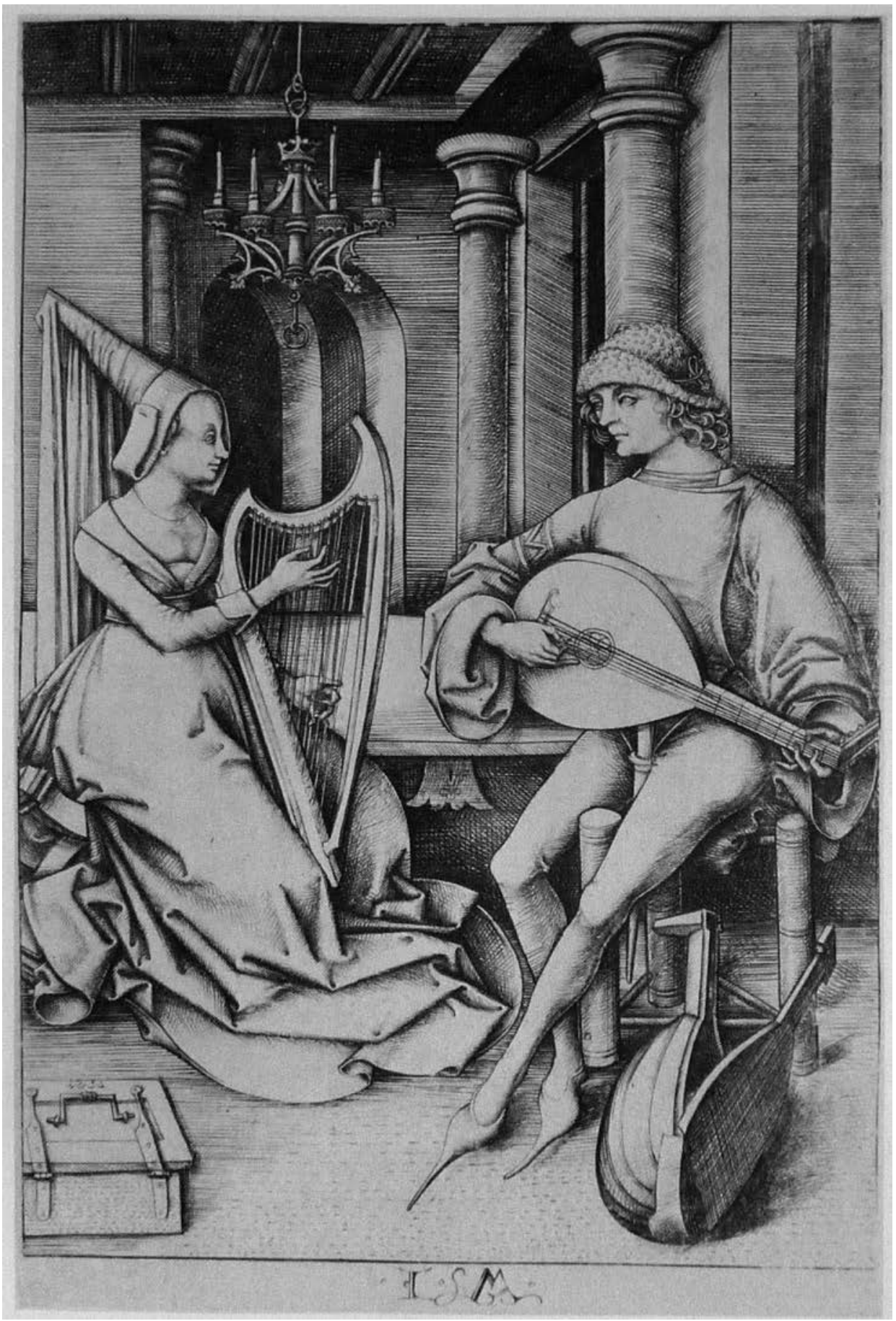

Obr. 7. Israhel van Meckenem - Hráč na lutnu a harfistka. Podl'a Strauss 1981, 169.

Abb. 7. Israhel van Meckenem - Lautenspieler und Harfenistin. Nach Strauss 1981, 169. 
Žena pootočená dol’ava, zachovaná iba čast' hlavy a krku. Na hlave má turbanovitú pokrývku s prísnym zavinutím hlavy, ktoré prechádza aj pod bradou, čo vidíme len v náznaku. Pokrývka zvyčajne lemuje tvár a prebytok visí vol'ne na chrbte, ale môže byt' upevnený aj okolo alebo popod bradu. Výjav zachytáva aj čast' zvýšeného goliera živôtika alebo košele, opät' však len v náznaku. Postava je rámovaná renesančnou nikou, prekrytou stlačeným oblúkom lunety, zdobenou jednoduchým listovcovým ornamentom.

Kat. č. 10 - Dominikánsky kláštor, fragment kachlice, portrétny (?) motív s polpostavou (?) neznámej ženy, či muža (tab. I:3). Fragment kachlice, zelená glazúra. Rozmery: $?(8,5) \times ?(10) \times 1 \mathrm{~cm}$. Nepublikované.

Zachovaný fragment znázorn̆uje pravú ruku od lakt’a po rameno. Zobrazený je priliehavý rukáv vrchného odevu, prípadne je to plášt' prehodený cez plecia. Na lakti je viditel'né riasenie. Za chrbtom je zobrazený vol'ne splývajúci kus látky. Môže íst' o plášt' alebo súčast' zavinutia hlavy ženy. Postava je rámovaná architektonickou renesančnou nikou. Zachovala sa z nej čast' spodného okraja a čast' steny s plastickou soklovou rímsou. Nika je zdobená vel'mi štylizovanou rozvilinou v podobe jednoduchých úponkov bez listov.

Kat. č. 11 - Košice, Dominikánsky kláštor, fragment kachlice, žánrový motív (tab. II:3). Fragment kachlice, režná. Rozmery: ?(12,7) × ?(9,3) × ?(1,2) cm. Lit.: Rusnák 2009, tab. 88-1.

Čast’ ženskej postavy, pootočenej doprava. Zachovaný dekolt, hlava a l'avé rameno. Z vrchného odevu je viditel'ná len čast’ živôtika s hlbokým výstrihom. Výstrih je lemovaný stuhou alebo kožušinou. Rukáv je členený stuhami a v oblasti ramena je prestrihovaný. Vo výstrihu vrchného odevu je viditel'ná košel’a, ktorá je upnutá ku krku so stojačikom. Hlavu pokrýva čepiec, zakrývajúci vlasy aj uši. Zdobený je siet’kou, prípadne stuhami v pásoch s prišívanými perlami. Na hlave je upevnený ozdobnou stuhou.

Kat. č. 12 - Košice, Dominikánske námestie11,dvafragmentykachlíc,žena(?),portrétny (?) motív (tab. II:4). Fragmenty kachlíc, zelená glazúra. Rozmery: ?(4,9) $\times ?(7,7) \times ?(0,6) \mathrm{cm}$ a $?(3,8) \times ?(4,8) \times ?(0,7) \mathrm{cm}$. Nepublikované.

Zachoval sa iba l'avý rukáv od ramena po laket' a čast' šiat na pleci a drieku. Rukáv delený stuhami na tri časti. Jednotlivé časti sú členené prestrihmi, z ktorých dekoratívne vystupuje košel’a. Náznak výstrihu (pravdepodobne vel'ký lemovaný „V“ výstrih), tesný živôtik.

Kat. č. 13 - Košice, Dominikánsky kláštor, kachlica, Lukrécia (?) (obr. 8). Fragment kachlice, zelená glazúra. Rozmery: $24,5 \times 17,5 \times 7$ cm. Lit.: Rusnák 2009, s. 108, tab. 87 .

Postava z výjavu evokuje na prvý pohl'ad skôr muža, viac tomu napovedá i odev, ikonografia s proti sebe obráteným mečom však poukazuje na Lukréciu, prípadne na Dido, Vergiliovu král'ovnú Kartága, berúcu si život. Tvárová čast' na kachlici chýba. Postava je mierne pootočená, zobrazená približne od výšky kolien. Odev tvorí hrubý kabát, zvaný giornea, alebo šuba s vel'kým vyhnutým go-

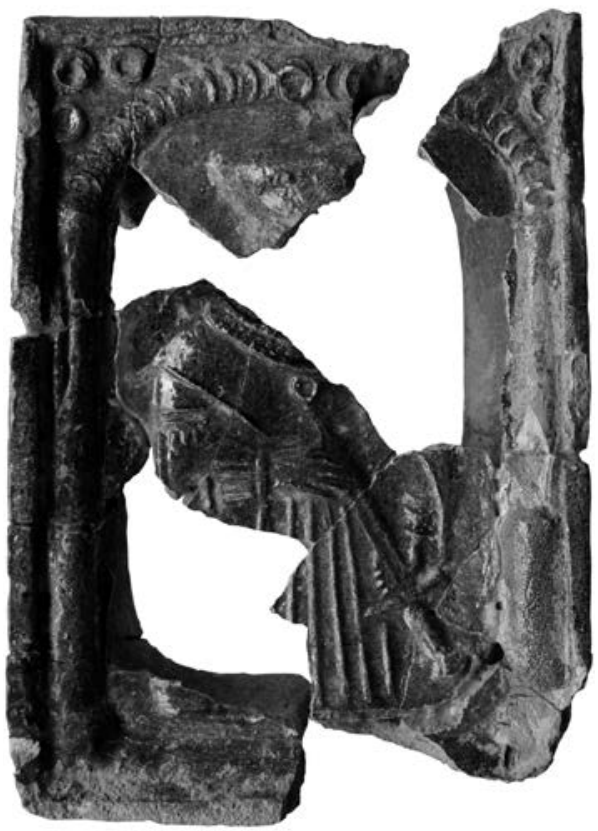

Obr. 8. Košice, Dominikánsky kláštor. Kachlica s vyobrazením Lukrécie. Kat. č. 13.

Abb. 8. Košice, Dominikanerkloster. Kachel mit Darstellung der Lucretia. Kat. Nr. 13. 
lierom, niekedy podšitým kožušinou. Kabát je vol'ného zvonovitého strihu, riasený a v záhyboch vol’ne splývajúci až po kolená. Rukávy sú členené a zdobené pravdepodobne prestrihmi v dvoch úrovniach. Môžu byt' súčast'ou odevu, ktorý má postava oblečený pod šubou. Na krku má, zdá sa, masívnu ret’az. Pokrývku hlavy tvorí baret, hlava sa však nezachovala. Figurálny výjav je rámovaný vel'mi štylizovanou renesančnou nikou.

Kat. č. 14 - Košice, Hlavná 110, fragment kachlice (?), žánrový motív (?) (tab. I:6). Fragment prelamovanej kachlice, zelená glazúra. Rozmery: ?(5) ×?(7) ×?(1,7) cm. Nepublikované.

Žena zobrazená zboku, z pravej strany. Zachovala sa hlava a pravá ruka od pleca po laket'. Z odevu je vidiet' len rukáv, ktorý je v oblasti ramena naberaný, d’alej po laket' zúžený, rovný a v lakti opät' naberaný. Pokrývku hlavy tvorí pravdepodobne čepiec zdobený perlami a stuhou, vol'ne visiacou na chrbát. Remeselné zhotovenie, prípadne i glazovaná poleva, neumožňuje lepšie rozpoznat' detaily. Rovnako sa nedá s istotou povedat', že ide o fragment čelnej dosky kachlice. Črep je pomerne tenký a nedá sa vylúčit, že je pozostatkom nálepu keramickej nádoby.

Kat. č. 15 - Košice, Dominikánske námestie 11, fragment kachlice, žánrový alebo mytologický motív (tab. I:7). Fragment kachlice, zelená glazúra. Rozmery: ?(5) $\times ?(7,1) \times ?(0,7) \mathrm{cm}$. Nepublikované.

Malý fragment zachytáva l’udskú tvár z profilu s výrazným golierom i pokrývkou hlavy. Zobrazenie je jednoduché a štylizované, čo neumožňuje jednoznačnú interpretáciu výjavu. Mohlo by íst' o žánrový motív zachytávajúci ženu s riaseným golierom košele, tesne zapnutým okolo krku a s pokrývkou hlavy, ktorú tvorí zdobený čepiec. Môže však íst' aj o spracovanie mytologického motívu s vyobrazením antického bojovníka s prilbou na hlave. Takéto scény, aj pre neznalost' dobových reálií, priam nabádali k individualistickému a štylizovanému vyobrazeniu.

Kat. č. 16 - Košice, Dominikánsky kláštor, fragment kachlice, náboženský alebo žánrový motív (tab. I:5). Fragment kachlice, zelená glazúra. Rozmery: ?(7,2) $\times ?(8,5) \times ?(0,8) \mathrm{cm}$. Nepublikované.

Postava zobrazená zozadu, so zachovanou dolnou čast'ou tela a nohami. Dlhý vol'ný odev siaha až po chodidlá. Ako obopína nohy, plasticky sa vydúva. Na chrbte a pod zadkom je nariasený, prípadne je prekrytý ešte pláštom. Naznačenú obuv tvoria uzavreté topánky. Fragment výjavu dopíňa výseč kruhovej pásky, plasticky zdobenej drobnými hviezdičkami.

\section{Odevy $\mathrm{z}$ foriem a kachlíc}

Predstavili sme si nevel'kú kolekciu kachl’ových výrobkov s ústredným figurálnym výjavom, ktorých ikonografická náplň je rôzna, no spája ich dobové vyobrazenie odevov, ktoré majú postavy na sebe. Ako kritérium sme si zvolili šaty zobrazených, pestrost' motívov nie je prekážkou. Už prvotnou obhliadkou možno odevy z kachlíc chronologicky rozdelit' do dvoch skupín. Ide o vyobrazenia šiat v ešte pretrvávajúcej neskorogotickej móde a o šaty, ktoré už vypovedajú o renesančnom štýle obliekania.

Neskorogotický odev je zachytený na forme so žánrovým motívom muža a ženy pri pradení (obr. 2; kat. č. 1), na fragmente s postavou muža vo vol’nom odeve s plášt’om (tab. I:4; kat. č. 8) a na formách s náboženskými motívmi Márie s Ježiškom (obr. 3; kat. č. 2), sv. Petra (obr. 4; kat. č. 3) i sv. Krištofa (tab. II:1; kat. č. 4). Všetky formy pochádzajú z Dominikánskeho nám. 11. Nastupujúcu renesančnú módu reprezentujú prevažne postavy na žánrových výjavoch, ako sú kachlice s motívom zasnúbenia z Mäsiarskej 57/A (obr. 5; kat. č. 5) a Hlavnej 16 (obr. 6; kat. č. 6), či kachlica z Dominikánskeho kláštora (tab. II:3; kat. č. 11). 

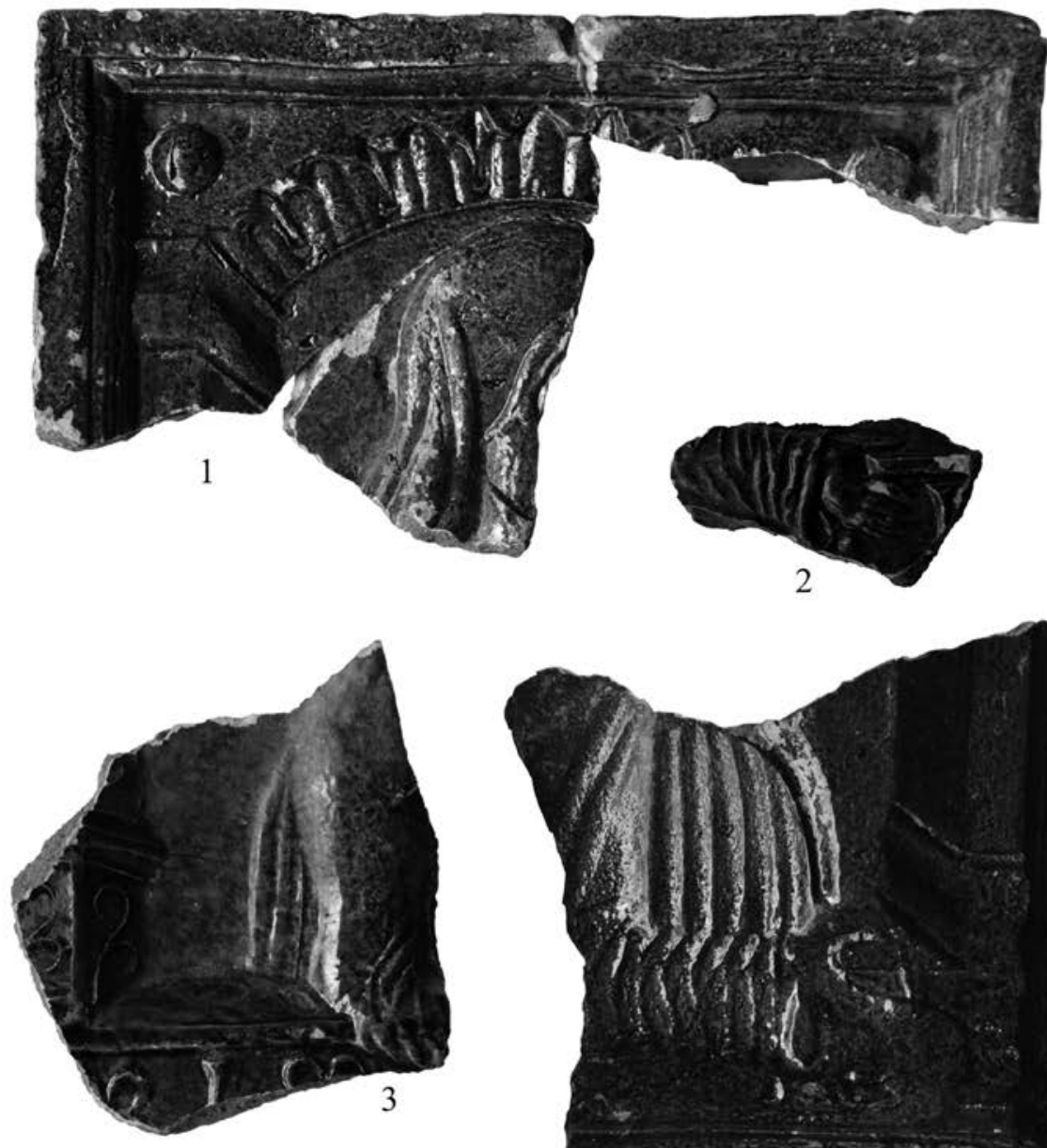

0 $5 \mathrm{c}$
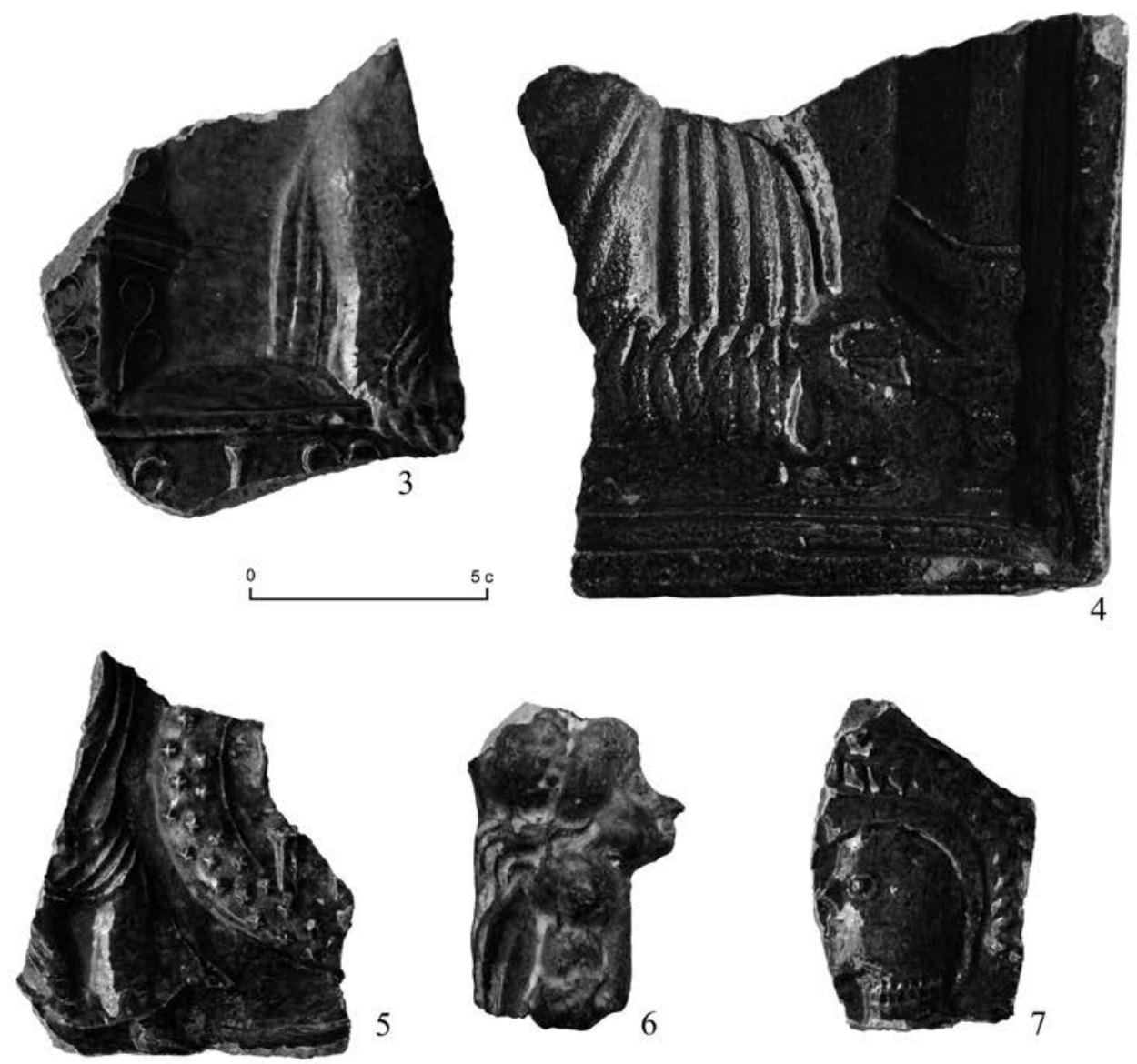

5
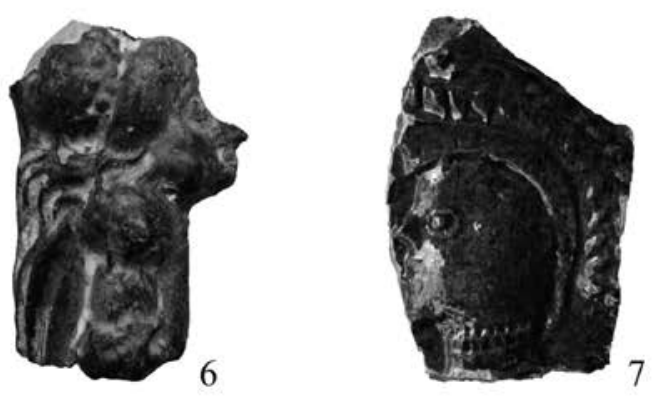

Tab. I. Košice, Dominikánske nám. 11: 1 - kat. č. 9, 4 - kat. č. 8, 7 - kat. č. 15; Dominikánsky kláštor: 2 - kat. č. 8, 3 - kat. č. 10, 5 - kat. č. 16; Hlavná 110: 6 - kat. č. 14.

Tab. I. Košice, Dominikanerplatz. 11: 1 - Kat. Nr. 9, 4 - Kat. Nr. 8, 7 - Kat. Nr. 15; Dominikanerkloster: 2 - Kat. Nr. 8,3 Kat. Nr. 10, 5 - Kat. Nr. 16; Hauptstr. 110: 6 - Kat. Nr. 14. 

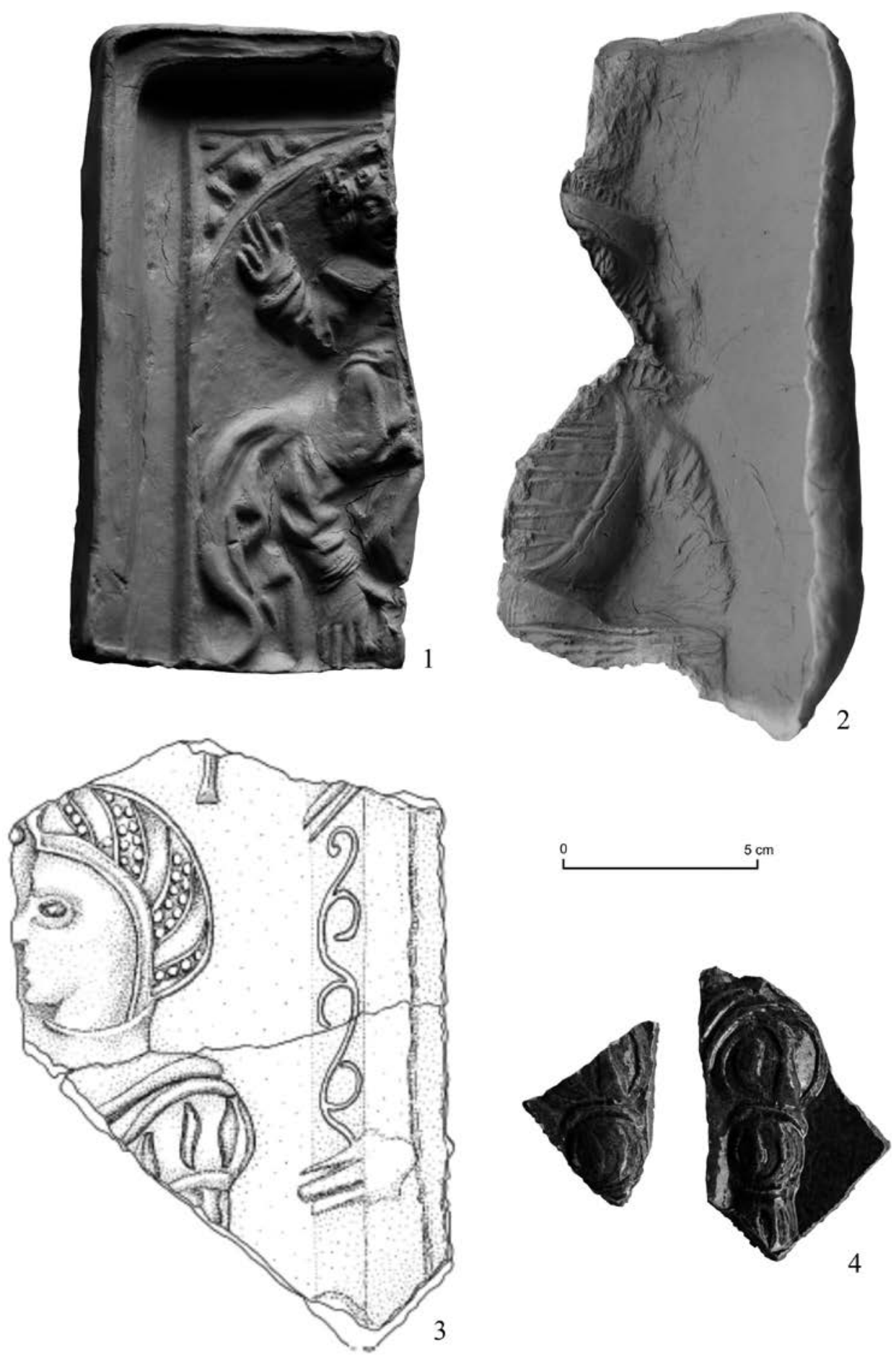

Tab. II. Košice, Dominikánske nám. 11: 1 - kat. č. 4, 2 - kat. č. 7, 4 - kat. č. 12; Dominikánsky kláštor: 3 - kat. č. 11.

Tab. II. Košice, Dominikanerplatz. 11.1 - Kat. Nr. 4, 2 - Kat. Nr. 7, 4 - Kat. Nr. 12; Dominikanerkloster: 3 - Kat. Nr. 11. 


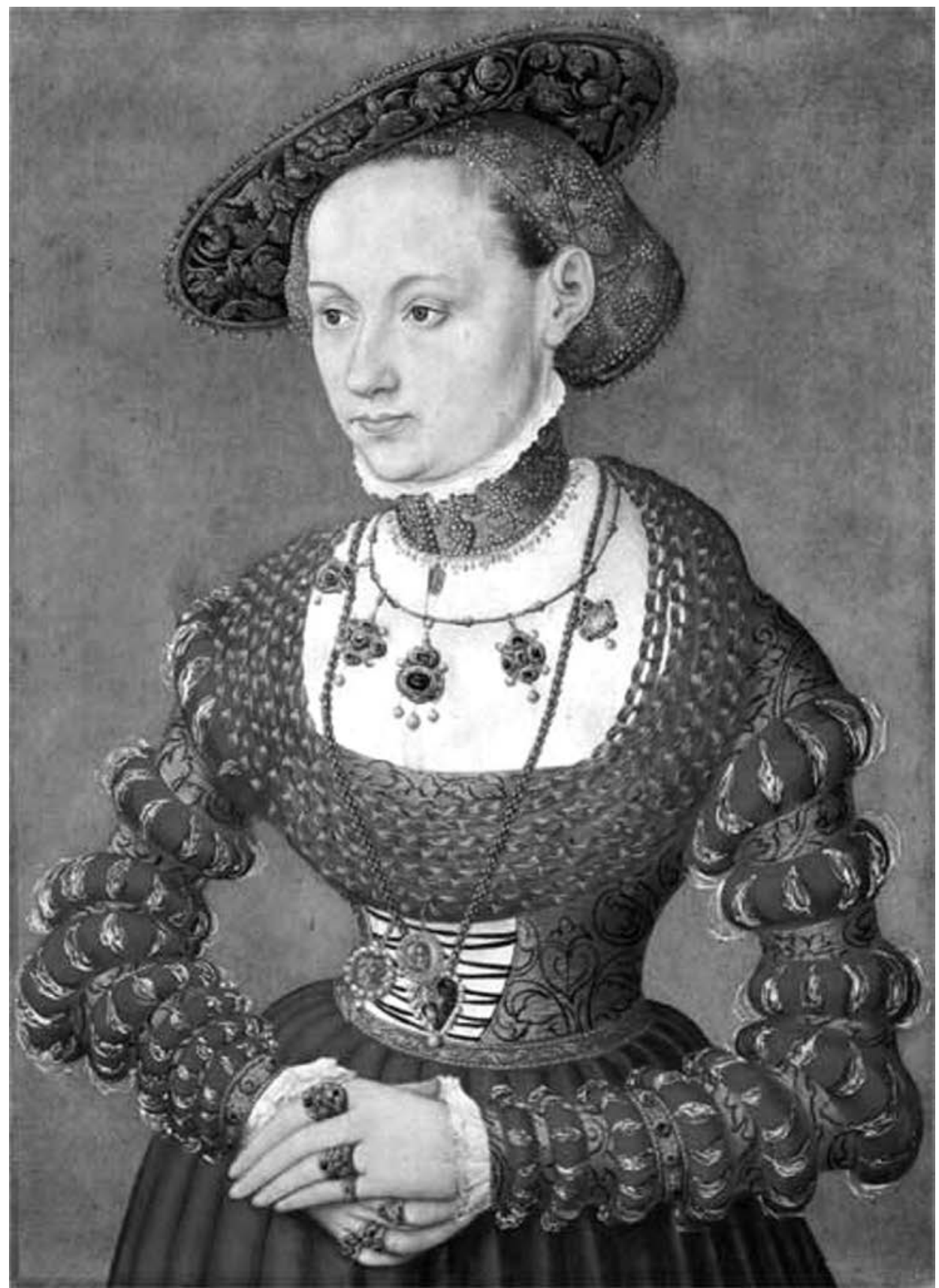

Obr. 9. Lucas Cranach ml. - Portrét Agnes von Hayn. Podl'a Cranach 1543.

Abb. 9. Lucas Cranach d.J. - Porträt von Agnes von Hayn. Nach Cranach 1543. 


\section{Vrchný a spodný odev}

Neskorogotický ženský aj mužský odev zobrazovaný na kachliciach najčastejšie je vrchný súkenný odev, nazývaný sukňa (Kovačevičová 1987, 174, obr. 238; Zubercová-Hasalová-Šidlíková-Vančo 2014, 46). Takto sú označované dlhé šaty s rukávmi alebo aj bez rukávov. Vyvinuli sa z pôvodného stredovekého odevu a v dobových prameňoch sa nazývajú tunika (Sendeková 2013, 61; Zubercová 1988, 53). Bol to strihovo nenáročný a vol’ný odev doplnený opaskom, čo mu zabezpečilo širokú obl'ubu a dlhodobé pretrvávanie (Zubercová-Hasalová-Šidlíková-Vančo 2014, 49-50). Košické nálezy kachlových výrobkov dokladajú využitie sukne u mužov aj žien. Sú dlhé alebo krátke, vol'ného, bohato riaseného strihu, siahajúce ku krku s okrúhlym výstrihom. Dlhú sukňu nosili ženy, ale aj muži, ako nám dokladá vyobrazenie muža pri pradení pod dozorom ženy (obr. 2; kat. č. 1). Muži nosili aj kratší variant, ktorý siahal len pod zadok, čo možno vidiet' na kachlici sv. Krištofa (Chovanec 1990, 393, obr. 14). Dlhší variant siahal po kolená, takú sukňu má oblečenú sv. Jakub (Chovanec 2005, 258, F11), alebo po členky, ako to môžeme vidiet' na forme s vyobrazením sv. Petra (obr. 4; kat. č. 3) a kachlici so sv. Jánom Almužníkom z Pariča (Chovanec 1990, 393, obr. 13). Muži nosili vrchný odev vol’ne splývajúci k nohám (obr. 2; kat. č. 1) alebo stiahnutý v páse opaskom, čo dokladajú vyobrazenia sv. Petra (obr. 4; kat. č. 3), sv. Krištofa (tab. II:1; kat. č. 4), ako i sv. Jána a sv. Jakuba. Ženy vyobrazené na košických nálezoch, ako Madona s diet’atom (obr. 3; kat. č. 2) a žena pri pradení (obr. 2; kat. č. 1), majú vrchné šaty stiahnuté opaskom umiestneným vyššie, ako je skutočný pás, čím sa predlžuje silueta dolnej časti tela. Spodný odev, košela, je v tomto období ešte neviditel'ný prvok módy a prakticky sa nedostáva na povrch spod šiat. Na vrchný odev si muži aj ženy obliekali plášt' podšitý kožušinami alebo podšívkami. Ženy ho nosili symetricky položený na pleciach, zopnutý párovými sponami a šnúrami (Zubercová-Hasalová-Šidlíková-Vančo 2014, 48). Plášte siahali k zemi a len postupne sa skracovali do polovice lýtok, po kolená alebo tesne pod zadok (Šimša 2014, 14). Ženy nosili plášte dlhé po zem, ako to môžeme vidiet' na forme s výjavom Madony s diet’at'om (obr. 3; kat. č. 2) či na kachlici so sv. Katarínou z Pariča (Chovanec 2005, 258, F10). Početné doklady, samozrejme, nachádzame na výjavoch z oltárnych tabul'ových malieb. Pri zachovaní dobovej i regionálnej blízkosti môžeme spomenút' napríklad Korunovanie Panny Márie v Spišskej Kapitule z obdobia okolo roku 1499 (Fajt 2003, 405, obr. 351) alebo známu rožňavskú Meterciu z roku 1513 (Metercia 2008-2011). Ženský plášt' z výjavu Madony s diet’atom je na hrudi zopnutý párovou sponou a dvojicou ozdobných šnúr, preto sa okraje plášt’a na hrudníku nedotýkajú, ale odhal'ujú šaty v hornej časti tela. Ženy nosili vol’ne splývajúce plášte so zahalenými ramenami a rukami, ale s odhalenou prednou častou šiat. Párovými sponami zopnuté plášte s pomocou ozdobných šnúr sú často zobrazené na tabul'ových mal'bách oltárov, napríklad z dielne Majstra Petra alebo Godera v Prešove z rokov 1497-1506 (Kovačevičová 1987, 129, obr. 164). Muži nosili plášte siahajúce pod zadok ako sv. Krištof (Chovanec 1990, 393, obr. 14) alebo po členky ako sv. Peter (obr. 4; kat. č. 3). Plášte mali kruhový strih, priliehali ku krku a rozširovali sa smerom k zemi. Mužské plášte boli zopnuté jednou sponou pod krkom, ako to môžeme vidiet' na forme so sv. Petrom či na kachliciach so sv. Krištofom a sv. Jakubom (Chovanec 1990, 393, obr. 14), čím sa okraje plášt’a na hrudníku dotýkajú a zahal'ujú hornú čast’ tela. Muži majú preto plášt’ prehodený cez plecia dozadu (všetci spomínaní svätí, okrem sv. Petra).

Na ôsmich predstavených kachlových výrobkoch už môžeme vidiet' bud' nastupujúce renesančné vplyvy v neskorogotickej móde, alebo už plne rozvinutú renesančnú módu. V obliekaní sa už viditel'ne vyčleňuje spodný odev, košel’a. Pri vrchnom odeve sa už rozlišuje niekol'ko druhov. Košel’a sa už koncom 15. storočia začína objavovat' ako dekoratívny prvok v prestrihávaných rukávoch šiat (Zubercová 1988, 54) a stáva sa dôležitým odevným prvkom v mužskom aj ženskom renesančnom odeve (Zubercová-Hasalová-Šidlíková-Vančo 2014, 52). Pôvodný gotický odev bol stále užší a postupne začal byt' prestrihovaný na lakt’och a pleciach. Košel'a tak čoraz viac dekoratívne vystupovala na povrch. Košele mali pôvodne hlboký okrúhly alebo oválny výstrih a bohato riasené rukávy (Zubercová 2001, 67). Začiatkom 16. storočia sa výstrih začína st’ahovat' stále viac ku krku a švy a lemovanie sú zdobené farebnými výšivkami a perlami, používajú sa 


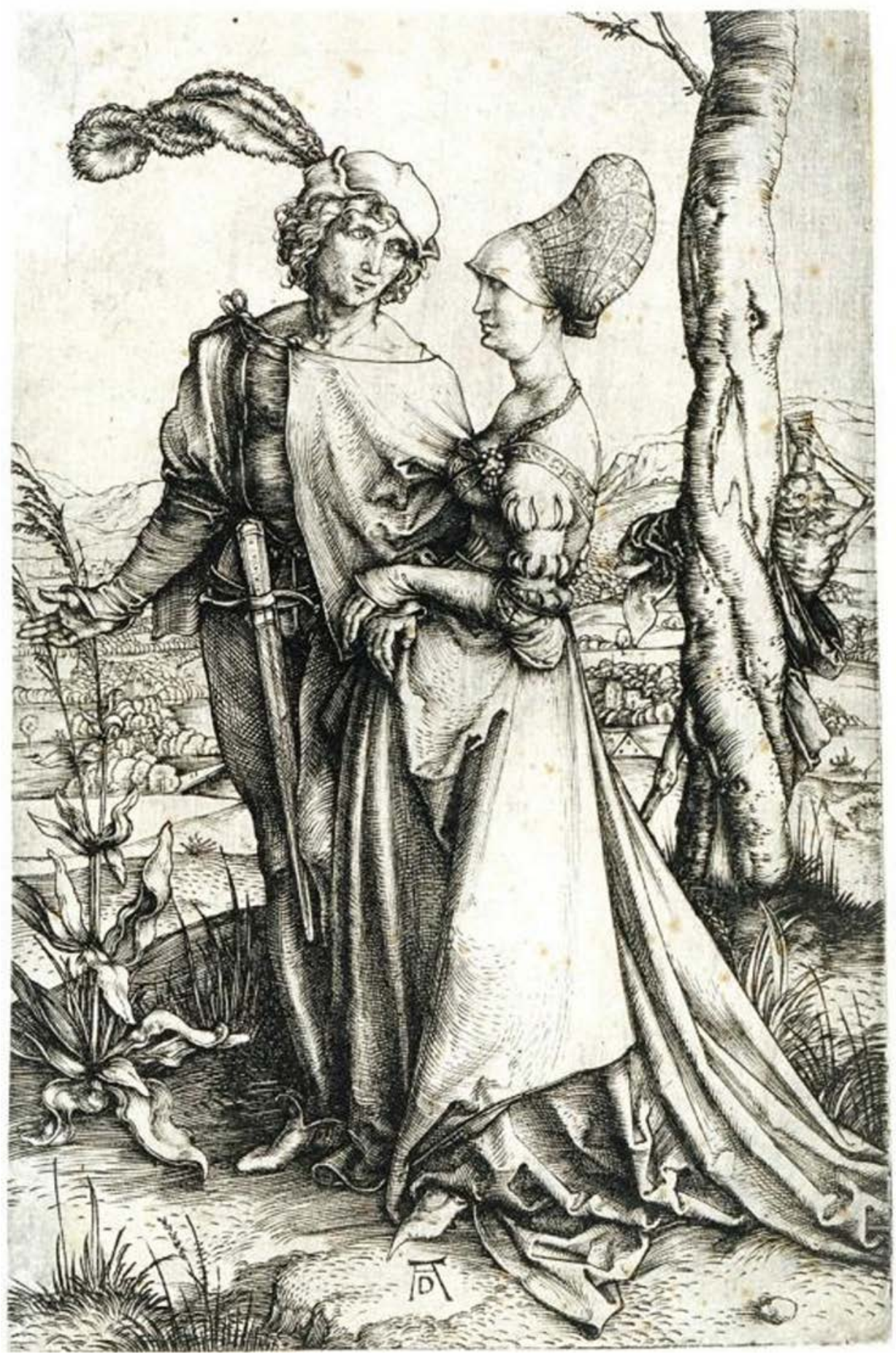

Obr. 10. Albrecht Dürer - Pár na prechádzke sledovaný smrt'ou. Podl’a Dürer 1498.

Abb. 10. Albrecht Dürer - Junges Paar durch Tod oder der Promenade bedroht. Nach Dürer 1498. 


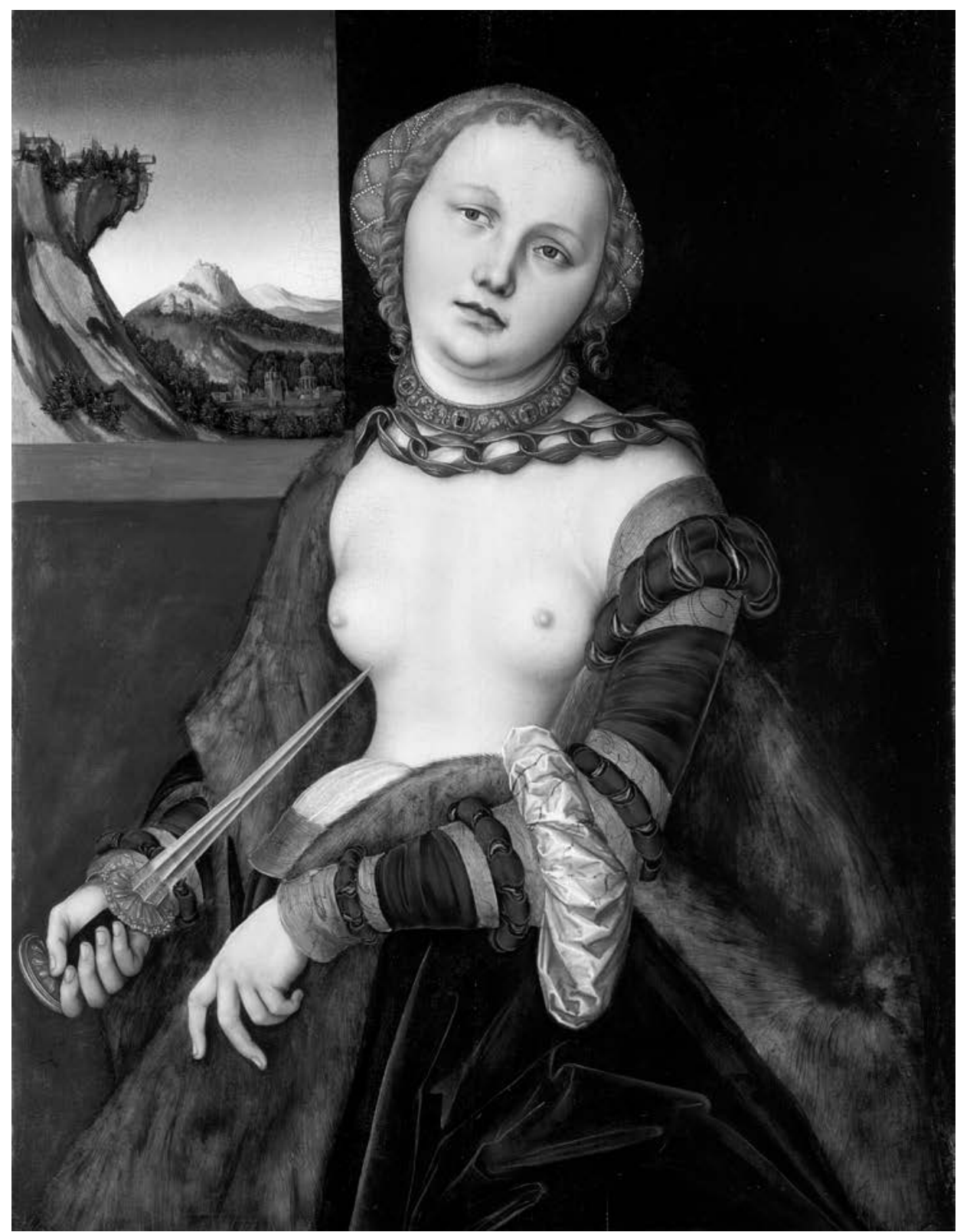

Obr. 11. Lucas Cranach st. - Lukrécia. Podl'a Cranach 1530.

Abb. 11. Lucas Cranach st. - Lucretia. Nach Cranach 1530.

čipkové vložky (Zubercová 1998b, 229). Košela, spodný odev žien a mužov, je viditel’ná na šiestich kachliciach. V štyroch prípadoch je to ženská košel’a a v troch prípadoch mužská. Zobrazená je zväčša iba v náznakoch, no i to nám umožňuje vytvorit' si obraz o jej rôznorodosti. Žánrová kachlica s motívom zásnub z Mäsiarskej 57/A (obr. 5; kat. č. 5) zobrazuje na ženských a mužských šatách hlboký výstrih košele, ukončený zdobeným lemom. Predpokladajme, že naznačená výzdoba na leme je hustá ozdobná výšivka, podobne ako to poznáme napríklad na svadobnej košeli Márie Habsburskej z roku 1522 (Zubercová 2001, 67). V tomto prípade majú muž aj žena 


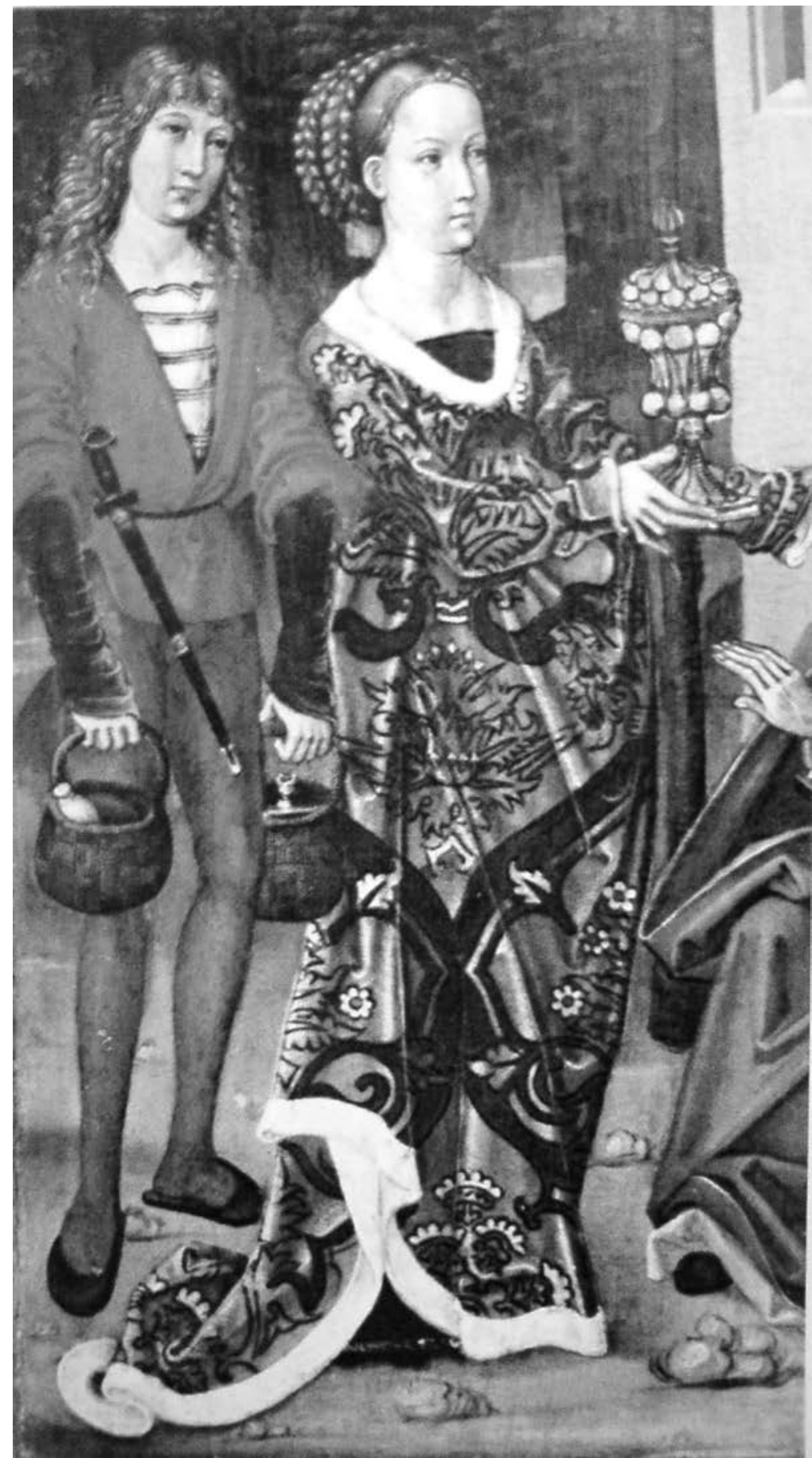

Obr. 12. Detail tabul'ovej mal'by z oltára v Kostole sv. Antona a sv. Pavla Pustovníka v Banskej Bystrici - Sásovej. Podl’a Kučera-Kostický 1990, 136, obr. 247.

Abb. 12. Detail eines Tafelbildes vom Altar in der St. Anton-und-Paul-Kirche in Banský Bystrica - Sásová. Nach KučeraKostický 1990, 136, Abb. 247. 
oblečenú rovnakú košel'u. Inak tvarovaná je košel’a na fragmente kachlice s vyobrazením ženy z Dominikánskeho kláštora (tab. II:3; kat. č. 11), zobrazujúcej l’avý profil a rameno v šatách. V hlbokom výstrihu vrchných šiat má žena oblečenú košel’u siahajúcu až k brade. Pri krku upevnená košel’a býva bohato riasená a stiahnutá do ozdobnej manžety, často zdobenej vyšívaním v širokom výstrihu vrchných šiat. Takto zdobenú košel’u má oblečenú napríklad sv. Barbora na tabul'ovej mal'be z roku 1509 v Kostole Panny Márie v Banskej Bystrici (Šugár 2003, 489), často zobrazené ich vidíme i na portrétoch L. Cranacha st. i ml. (obr. 9; Cranach 1543). Dekoratívne uplatnenie košele v prestrihovaných rukávoch ženských a mužských šiat môžeme vidiet' najmä na dvoch fragmentoch kachlice znázorňujúcej l’avé rameno ženy z Dominikánskeho kláštora (tab. II:3; kat. č. 11) a Dominikánskeho nám. 11 (tab. II:4; kat. č. 12). Šaty majú rukáv zdobený vo viacerých úrovniach kratšími, husto usporiadanými prestrihmi, ktoré umožňujú dekoratívne povyt’ahovanie husto nariaseného rukáva košele. Mužská košel’a je viditel’ná v dlhom prestrihu rukáva od ramena po laket', na vrchnom odeve muža z Hlavnej 16 (obr. 6; kat. č. 6). Dekoratívne má pôsobit' aj v hlbokom výstrihu jeho vrchného odevu, upevnenom šnurovaním. Rovnako to môžeme vidiet' aj na jednej z foriem z Dominikánskeho námestia 11 (tab. II:2; kat. č. 7).

Štýl obliekania v strednej Európe v 15. storočí ešte ovplyvňuje gotická móda, ktorá vrcholí na burgundskom dvore, zatial' čo $\mathrm{v}$ Itálii sa už v tom čase formuje renesančná móda (Zubercová-Hasalová-Šidlíková-Vančo 2014, 50). Jej vplyvy prenikajú do burgundskej módy vo forme tesne tvarovaných odevov, vystupujúcej košele, ozdobného šnurovania živôtika a priväzovaných rukávov (Kybalová 2001, 213-214). Nastupujúci trend výraznejšie neovplyvnila ani raná reformácia. V 15. storočí sa sukňa rozdelila na samostatne strihaný živôtik a sukňu (Zubercová-Hasalová-Šidlíková-Vančo 2014, 184). Šaty sú bud’ dvojdielne, skladajúce sa zo živôtika so šnurovaním a naberanej sukne, alebo jednodielne, s hlbokým výstrihom, vlečkou, prepásané vysoko pod prsiami (Zubercová 1988, 53). Koncom 15. storočia výrazne nastupuje prestrihávanie na rukávoch a dekoratívne šnurovanie. Najmä v Nemecku sa nosia vyššie čepce poduškovitého typu a siet'ky zo zlatých nití s perlami (Zubercová 1988, 54). Vrchný odev žien tvoria šaty, tzv. robe, charakteristické rozšírenou sukňou s vypasovaným živôtikom a zvýšeným pásom, s vel'kým výstrihom v tvare písmena „V“ (Kybalová 2001, 213), vyplneným ozdobnou predničkou (Kovačevičová 1987, 179). Z košických nálezov nachádzame takéto šaty na kachlici z Mäsiarskej 57/A (obr. 5; kat. č. 5). Žena má oblečené šaty so živôtikom s vel'kým „V“ výstrihom vyplneným predničkou. Rukávy sú dlhé a úzke, sukňa bohato riasená. Výzdoba na predničke naznačuje, že je použitá ozdobná látka s výrazným dekoratívnym vzorom. Výstrih aj prednička sú lemované, predpokladáme, že stuhami alebo pásmi farebne odlišnej látky. Rovnako riešený živôtik s „V“ výstrihom majú oblečené aj sv. Barbora, žena na kachlici s kartármi a Mária z kachlice s motívom jej Nanebovzatia z Trebišovského hradu (Chovanec 2005, 259, F16). Výstrih je vyplnený náprsenkou, predničkou, ktorá je ukončená rovno, ako na šatách ženy z Mäsiarskej 57/A (obr. 5; kat. č. 5) a sv. Barbory (Chovanec 1990, 392, obr. 11), alebo oválne, ako na šatách Panny Márie a ženy z dvojice kartárov z Trebišovského hradu (Chovanec 2005, 259, F16; 259, F14). Pre lepšiu ilustráciu, rovnako riešené šaty má mladá žena na oltárnej mal'be od Albrechta Dürera z roku 1503/1504 (Dürer 1503/1504). Žena má oblečené šaty ružovej farby s čiernym lemovaním „V“ výstrihu. Ten je vyplnený predničkou z červenej látky so zlatým lemovaním. Živôtik ženských šiat môže mat’ aj oválny výstrih, vo vnútri s náprsenkou, ako to môžeme vidiet' na šatách sv. Kataríny (Chovanec 2005, 258, F10), alebo ženy z vyobrazenia šlachtického páru z Trebišovského hradu (Chovanec 2005, 259, F15). S takto upraveným výstrihom sa môžeme často stretnút' na mal'bách Lucasa Cranacha st. (Cranach 1502). Na kachlici z Hlavnej 16 (obr. 6; kat. č. 6) chýba čast', ktorá zobrazuje živôtik, preto nevieme ako bol strihovo riešený. Šaty majú ešte gotickú siluetu s predíženou vlečkou na rozšírenej sukni. Rukávy sú rovné, dlhé, ukončené širokou manžetou. Odev, na ktorom sa už bežne používa prestrihovanie rukávov, reprezentujú dva fragmenty kachlíc, jeden z Dominikánskeho nám. 11 (tab. II:4; kat. č. 12), druhý z Dominikánskeho kláštora (tab. II:3; kat. č. 11). Šaty majú tesný živôtik s hlbokým výstrihom vyplneným košel’ou, ktorá siaha až pod bradu a je tesne zopnutá okolo krku. Zachovaná vrchná čast' rukáva od ramena po laket’ je členená troma radmi prestrihov, z kto- 


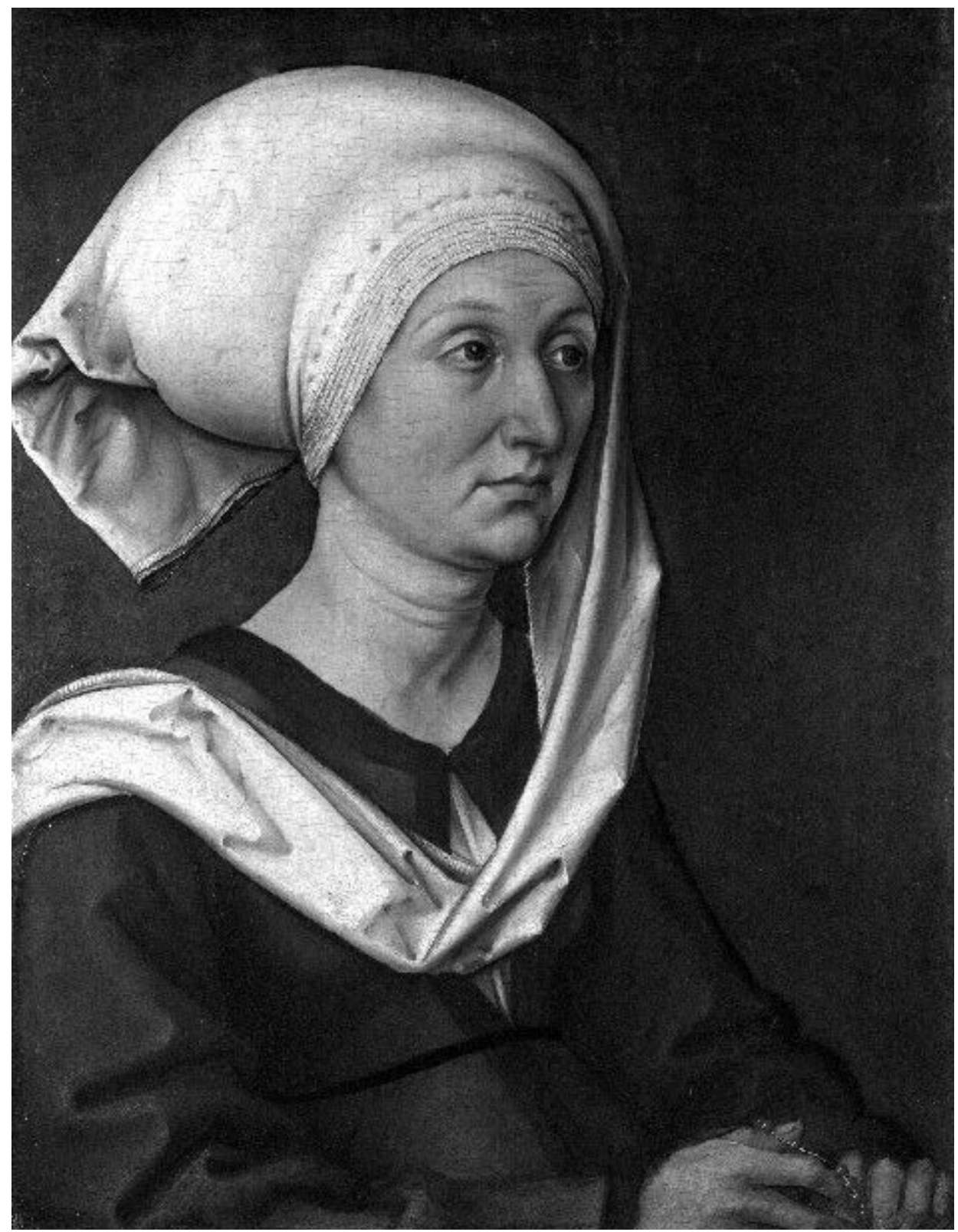

Obr. 13. Albrecht Dürer - Portrét matky, Barbary Holper. Podl'a Dürer 1490.

Abb. 13. Albrecht Dürer - Porträt der Mutter, Barbara Holper. Nach Dürer 1490.

rých dekoratívne vystupuje košel’a. Prestrihy sú vo viacerých úrovniach nad sebou oddelené pravdepodobne ozdobnými stuhami inej farby. Predpokladajme, že rukáv je dlhší ako samotná ruka a jeho vyhrnutím sa dosiahne uvol'nenie a roztvorenie prestrihov s vystupujúcou košel'ou. $\mathrm{S}$ prestrihovanými rukávmi sa $\mathrm{v}$ nemeckej oblasti stretávame už koncom 15 . storočia, vidíme ich napríklad na obraze dvojice na prechádzke od Albrechta Dürera z roku 1498 (obr. 10; Dürer 
1498). Šaty sa ešte strihovo nedelia na tesný živôtik a naberanú sukňu. V našom prostredí prestrihované rukávy môžeme vidiet' napríklad na tabul'ovej mal'be z Banskej Bystrice z roku 1519, nachádzajú sa na šatách s oválnym výstrihom, vyplneným ozdobnou predničkou (Kovačevičová 1987, 179, obr. 244). Prestrihované rukávy sú zobrazené aj na portréte Anny Jagellonskej od Hansa Malera zu Schwarz z roku 1519 (Maler 1519). Ich obl'uba, najmä na ženských šatách, pretrváva aj okolo polovice 16. storočia. Z početných dokladov na obrazoch Lucasa Cranacha ml. možno spomenút' portrét Agnes von Hayn z roku 1543 (obr. 9; Cranach 1543). Pozoruhodný je aj originál šiat, v ktorých bola pochovaná Anna Jagellonská v roku 1547 v Prahe (BravermanováKobrlová-Samohýlová 1994, 442, obr. 1). Šaty majú hlboký „V“ výstrih ukončený šnurovaním a bohato prestrihované rukávy vo viacerých úrovniach nad sebou, predelené stuhami. Ženy na kachliciach z Košíc majú bohato riasené sukne v páse, ako to môžeme vidiet' na šatách z Mäsiarskej 57/A (obr. 5; kat. č. 5) a Hlavnej 16 (obr. 6; kat. č. 6).

Na kachlici z Dominikánskeho kláštora (obr. 8; kat. č. 13) je zobrazený vrchný odev šuba, honosný teplý reprezentačný odev zo vzorových látok podšitý kožušinou, ktorý sa vel'kej obl'ube tešil už od druhej polovice 15. storočia. Šuby boli vol'né, vpredu po celej dížke otvorené, postupne zapínané gombíkmi, s vel'kými goliermi (Zubercová 1998a, 187). Šuba zobrazená na košickej kachlici má široký golier na pleciach. Dížku kabáta nevidíme, pravdepodobne siaha po kolená tak, ako to poznáme z mnohých vyobrazení. Rukávy sú vol'né a nad laktom prestrihnuté tak, aby ich bolo možné nechat' vol’ne visiace. V šubách sú častejšie zobrazovaní muži. Vidíme ich na dobových portrétoch, ako napríklad Thomasa Morea od Hansa Holbeina z roku 1527 (Holbein 1527). Motív na kachlici však dost' jednoznačne smeruje k postave Lukrécie. Odetú v šube ju často zobrazoval Lucas Cranach st. (obr. 11; Cranach 1530), takže tento kus odevu zvolenú ikonografiu nevyvracia.

Mužský vrchný odev je zobrazený na štyroch kachl'ových výrobkoch z prezentovaného súboru. V troch prípadoch je to krátky spodný kabátec, joppula, $\mathrm{s}$ „V“ výstrihom (obr. 5; kat. č. 5; obr. 6; kat. č. 6; tab. II:2; kat. č. 7). Reprezentuje už renesančný odev. Kabátce siahajú pod zadok, v hornej časti sú priliehavé a v páse stiahnuté opaskom. Odlišujú sa vyhotovením výstrihu. Muž zo snúbeneckého páru na kachlici z Mäsiarskej 57/A je oblečený v kabátci s „V“výstrihom, vyplneným podobne ako na ženských šatách zdobenou, lemovanou, rovno ukončenou predničkou. Rukávy má rovné a zatial' bez charakteristickej renesančnej výzdoby, prestrihovania. Vel'ký špicatý alebo oválny výstrih pridržiavaný šnurovaním vidíme na kabátci muža z Hlavnej 16 i z Dominikánskeho nám. 11. Takéto kabátce sú zobrazené na tabul'ovej mal'be oltára v Kostole sv. Antona a sv. Pavla Pustovníka z obdobia okolo roku 1500 v Banskej Bystrici-Sásovej (obr. 12; Kučera-Kostický 1990, 136, obr. 247) alebo v knižnej mal'be Baltazara Behema z 1505 (Stolot 1981, 57). Muž z Dominikánskeho nám. 11 má oblečený kabátec s oválnym hlbokým výstrihom, pridržiavaným šnurovaním. Kabátce podobných strihov, bez šnurovania alebo so šnurovaním, sú zobrazené napríklad na tabul'ovej mal'be oltára Kostola sv. Mikuláša v Prešove z rokov 1497-1506 (Kovačevičová 1987, 152, obr. 204). V rovnakom kabátci, ale bez šnurovania je vyobrazený Albrecht Dürera na autoportréte z roku 1498 (Dürer 1498a) alebo mladý muž na obraze páru na prechádzke z roku 1498 (obr. 10; Dürer 1498). Charakteristické renesančné zdobenie rukávov, tzv. prestrihy, sú zobrazené ako jeden dlhý prestrih od ramena po laket' len na rukávoch kabátca muža z Hlavnej 16 (obr. 6; kat. č. 6). Rukáv kabátca na forme z Dominikánskeho nám. 11 (tab. II:2; kat. č. 7) je naberaný.

Jeden zo zobrazených vrchných odevov z košických nálezov je plášt' pripomínajúci neskorogotický „,houppelande“, zopnutý pod bradou (tab. I:4; kat. č. 8). Zvonovitý strih s rozšírenou spodnou častou je dosiahnutý zošitím viacerých samostatných lichobežníkovitých dielov, ktoré splývajú v pravidelných záhyboch k zemi. Rukávy sú dlhé, vol’né, nariasené od lakt’a po zápästie tak, aby nepresahovali ruku. Doplnený býva opaskom v rôznych úrovniach (Zubercová-Hasalová-Šidlíková-Vančo 2014, 51). Pekným príkladom stredovekého „houppelande“ je zachovaný odev Jana Zhořeleckého z roku 1395 (Bravermanová 2006, 409, obr. 7, 8). Stredoveké „,houppelande“ prežíva aj v období renesancie (Kybalová 1996, 29). 


\section{Úprava vlasov, ozdoby a pokrývky hlavy žien}

Ženy sú zobrazené zväčša s rozpustenými dlhými, jemne zvlnenými vlasmi, prípadne majú vlasy zopnuté a doplnené čelenkou alebo zopnuté pod čepcom, či inou pokrývkou hlavy. Slobodné dievčatá gotickej doby nosia vlasy rozpustené, prípadne spletené do vrkočov obtočených okolo tváre, doplnené venčekom. Vydaté ženy si hlavu prísne zavinujú a vlasy zahal'ujú spolu s krkom aj bradou (Zubercová-Hasalová-Šidlíková-Vančo 2014, 47). Prostovlasé, nevydaté ženy z kachlíc z Mäsiarskej 57/A (obr. 5; kat. č. 5) a Hlavnej 16 (obr. 6; kat. č. 6) usvedčuje aj ikonografický motív zásnub. S kachlicou z Mäsiarskej 57/A je príbuzná i kachlica šlachtického páru z Pariča (Chovanec 2005, 259, F15). Zobrazené ženy majú vol'né rozpustené vlasy, doplnené čelenkou s výraznou ozdobou, alebo vrkoče plavej farby, obtočené okolo hlavy lemujúc tvár. Takto upravené a ozdobené vlasy sú vyobrazené napríklad na tabul'ovej mal'be oltára sv. Antona Pustovníka v Kostole sv. Juraja v Spišskej Sobote z obdobia okolo roku 1500 (Gerát 2013, 217, obr. V / 11) alebo na tabul'ovej mal'be Majstra Pavla z Levoče z roku 1520 (Kovačevičová 1987, 156, obr. 211). Pravda, vol’ne rozpustené vlasy má i Madona s diet’atom z formy z Dominikánskeho nám. 11 (obr. 3; kat. č. 2) a rovnako i sv. Katarína, či sv. Barbora na kachliciach z Pariča (Chovanec 2005, 258, F9, F10).

Vydaté ženy, ktoré si svoje vlasy spínali a zahal’ovali, vidíme na fragmentoch kachlíc z Dominikánskeho kláštora (tab. II:3; kat. č. 11) a Dominikánskeho nám. 11 (tab. I:1; kat. č. 9), či na kachlici s kartármi z Pariča (Chovanec 2005, 259, F14). Zobrazené zavinutie hlavy ženy z Dominikánskeho nám. 11 zahal'uje aj krk a má výrazný turbanovitý alebo poduškovitý tvar, z ktorého v zadnej časti visí prebytok látky. Podobnú pokrývku hlavy má Barbara Holper na portréte Albrechta Dürera z roku 1490 (obr. 13; Dürer 1490). Prísne zavinutie hlavy sa objavuje v rôznych podobách už na mal'bách z druhej polovice 15. storočia, ako napríklad na tabul'ovej mal'be Narodenie sv. Alžbety oltára sv. Alžbety v dóme sv. Alžbety v Košiciach z roku 1474-1477 (Suckale 2003, 366) alebo na tabul'ovej mal'be oltára Majstra MS z roku 1506 s výjavom Navštívenia Panny Márie (Šugár 2003, 484). Prísne zavinutú hlavu, krk a bradu má aj Magdaléna, manželka na epitafe Alexeja Thurzu z roku 1543, ktorý je z dielne Loya Heringa (Rusina a kol. 2009, kat. 142). Siet'kový čepiec na kachlici z Dominikánskeho kláštora je honosnou pokrývkou hlavy, zdobenou korálikmi. Poduškovitý čepiec zdobený dekoratívnou siet'kou je zobrazený na tabul'ovej mal'be s výjavom Esmerie s Alžbetou na oltári sv. Anny v Kostole sv. Jakuba v Levoči z obdobia okolo roku 1520 (Rusina a kol. 2009, kat. 195). Čepce zdobené siet’kou a korálikmi vidíme často na obrazoch Lucasa Cranacha st. (Cranach, okolo 1525).

\section{Úprava fúzov, vlasov a pokrývky hlavy mužov}

Aj muži dbali o svoj zovňajšok. Na kachliciach ich vidíme s upravenými bradami a vlasmi. Ako pri ženách, i tu sa stretávame s odlišnou úpravou vlasov a fúzov u mužov z náboženských motívov a mužov zo svetských motívov. Svätci majú vo všetkých prípadoch brady precízne zostrihnuté, menej časté, skoro až ojedinelé sú fúzy (sv. Jakub; Chovanec 2005, 258, F11). Brady lemujúce tváre s vyholenými lícami (sv. Ján Almužník; Chovanec 2005, 258, F12) alebo plne zarastené (sv. Krištof; Chovanec 2005, 259, F13) siahajú na hrudník, prípadne sú zostrihnuté tesne pod bradou, kopírujúc jej tvar. Brady sú rovné, jedine sv. Krištof má bradu upravenú do výrazných lokní. Pri svetských vyobrazeniach mužov má bradu lemujúcu tvár s vyholenými lícami len jeden, a to na kachlici šlachtického páru z Pariča (Chovanec 2005, 259, obr. F15). Muži nosia upravené aj vlasy. Prevažne ich majú zostrihnuté po ramená ako sv. Ján alebo sv. Krištof (Chovanec 2005, 258, obr. F12; 259, obr. F13), ojedinele nad uši ako sv. Peter na kachlici z Dominikánskeho nám. 11 (obr. 4; kat. č. 3).

Pokrývky hláv mužov sú zobrazené na kachliciach so svetskými motívmi. Na kachlici z Dominikánskeho nám. 11 (tab. II:2; kat. č. 7) postave chýba čast' hlavy, čo nám st’ažuje presnejšie určit' typ pokrývky. Do úvahy prichádza nízky klobúčik pokrývajúci len vrchnú čast' hlavy, taký, ako na tabul'ovej mal'be Majstra Petra alebo Godera v Prešove z rokov 1497-1506 (Kovače- 
vičová 1987, 152, obr. 204), alebo na obraze dvojice na prechádzke od Albrechta Dürera z roku 1498 (obr. 10; Dürer 1498). Muž však môže mat na hlave i čelenku, prípadne čiapku z viacerých druhov látky. Iným typom pokrývky hlavy je baret, ktorý zvyčajne zakrýva hlavu až pod uši (obr. 8; kat. č. 13). Baret na kachlici z Dominikánskeho kláštora uši neprekrýva, má okolo nich výrezy. V hornej časti je rozšírený a plocho ukončený. Podobný baret má Erasmus Rotterdamský na portréte od Hansa Holbeina ml. (Kybalová 1996, 53). Opät' je nutné pripomenút', že v našom prípade by mal baret patrit' Lukrécii. Ak by sme mali postavy vnímat' len podla toho, čo majú oblečené, vd’aka pokrývke hlavy by bolo obtiažne stotožnit' ju so ženou.

\section{Nohavice}

Nohavice sú zobrazené na kachlici so sv. Krištofom (Chovanec 2005, 259, obr. F13) a kachlici so snúbeneckým párom z Hlavnej 16 (obr. 6; kat. č. 6). V oboch prípadoch ide o priliehavé pančuchové nohavice, vzadu spojené švom a vpredu uzavreté krytím (Zubercová-HasalováŠidlíková-Vančo 2014, 52). Pančuchové nohavice sv. Krištofa môžu zároveň tvorit' i topánky podšité koženými podrážkami.

\section{Obuv}

Na niekol'kých kachl'ových výrobkoch je zobrazená i obuv mužov a žien. Celú obuv vidíme u muža z páru na kachlici z Hlavnej 16 (obr. 6; kat. č. 6) a ženy na forme s motívom sveta obráteného naruby (obr. 2; kat. č. 1). Celé ženské topánky sú zobrazené spredu i z vonkajšej a vnútornej strany. Sú nízke, siahajúce nad členky. Vnútorná strana topánky je uzavretá. Horná a vonkajšia strana sú prelamované. Koža je prerezaná, čím vytvára remienky. Jedinou celou zobrazenou mužskou obuvou sú čižmy siahajúce až na lýtka s vyhnutým okrajom ako manžetou. Je to celokožená uzavretá obuv, akú môžeme vidiet' napríklad na tabul'ovej mal'be v Hronskom Beňadiku zo začiatku 16. storočia (Kovačevičová 1987, 178, obr. 243). Častejšie sú zobrazované len špičky špicatých topánok vyčnievajúcich spod šiat, čo sa bežne stáva najmä pri zobrazeniach žien (Sendeková 2013, 63). Špičky topánok sú viditel'né i na kachlici Madony s Ježiškom (obr. 3; kat. č. 2) a viacerých vyobrazeniach žien na kachliciach z hradu Parič (Chovanec 2005, 50-53, obr. 28, 37, 39, 41). Špička topánky trčí aj spod odevu muža pri pradení (obr. 2; kat. č. 1).

\section{Záver}

Aj ked' kachlice predstavujú skôr okrajový prameň poznania pre skúmanie dobových foriem obliekania, dokázali poskytnút' pestrý a autentický doklad o neskorogotickej a ranorenesančnej móde. Predstavené nálezy nám odhalili tri skupiny šiat. Popri ešte stredovekých odevoch sa objavujú renesančné prvky v neskorogotickej móde, ktorú nakoniec vystrieda renesančná móda. Napriek takto priamočiaro načrtnutému chronologickému toku, prenikanie nových módnych prvkov i pretrvávanie oblúbenosti tých starších boli dlhodobé, pozvol'né procesy, existujúce súbežne popri sebe, pričom rozličné society na ne reagovali rôzne citlivo. Nahliadnut' do nich a lepšie ich pochopit' nám pomáha i materiál, ktorý niekedy odhalí na jednom artefakte použitie zdanlivého anachronizmu vedla progresívnych prvkov.

Určitý chronologický posun sa dá napríklad pozorovat' pri porovnaní grafických predlôh nemeckých majstrov, najmä Majstra E. S. a košických foriem (resp. trebišovských kachlíc), ktoré boli vytvorené podl'a nich. Majster E. S. bol činný ešte v rokoch 1450-1467, pec palatína Imricha Perényiho datuje J. Chovanec do obdobia po roku 1504 (2005, 39). Ich renesančné zaradenie je napriek gotickému oblečeniu zobrazených postáv z kachlíc zjavné. Reprezentuje ho štylizované architektonické rámovanie či polychrómia. Ak teda košická kachliarska dielňa niekedy na začiatku 16. storočia vyrábala kachlice s renesančným rámovaním v kombinácii s ešte gotickým figurálnym motívom, mohlo to byt' preto, že matricami podl'a modernejších grafických predlôh ešte nedisponovala, ale napríklad aj preto, že po starších ikonografických programoch bol u čas- 
ti objednávatel'ov stále dopyt, aj ked' už akceptovali nové formy okrajových dekorácií. To, či bolo oblečenie postáv zobrazených na kachlici v súlade s aktuálnou módou, záviselo viac od konkrétnej preferencie objednávatel'a, výberu motívov a ponuky dielne. Okrem toho je známe, že Ishrael van Meckenem, žiak a pokračovatel' Majstra E. S., bol činný v rokoch 1465-1503, čo už nepredstavuje taký výrazný posun. Mnohé z jeho prác boli kópie, i kópie prác Majstra E. S. Navyše, van Meckenem povýšil nový fenomén tlačených grafík na skutočný predmet obchodu. Bolo by azda bližšie pravde prikladat' väčšiu zásluhu za šírenie spomenutých grafických predlôh do našich oblastí skôr jemu než Majstrovi E. S.

Pri skúmaní rôznorodých procesov, ktoré mali vplyv na kachliarsku produkciu prvých desat'ročí 16. storočia, by bolo zaujímavé zamerat' sa i na lutherskú reformáciu. Tá sa v hornouhorských mestách začala šírit' s vel'kou razanciou už od 20. rokov 16. storočia (Kónyová-Kónya 2010, 12). V súčasnosti síce nedisponujeme dostatkom materiálu, aby sme dokázali postihnút' napríklad jej vplyvy na vývin preferencií ikonografických programov, je to však zaujímavá výzva do budúcnosti. Z neskoršieho vývoja je známe, že mestá Pentapolitany sa aj pod duchovným vodcovstvom umierneného Leonarda Stöckela dokázali viac-menej úspešne vyhnút' hrozbe protestantského ikonoklazmu (Škoviera 2009, 68). Nie je teda dôvod predpokladat', že došlo k zásadnému utlmeniu používania určitých motívov, napríklad mariánskeho, či motívov svätých, aj ked' im zmenené náboženské prostredie v meste prestalo žičit'. Pokles ich oblúbenosti je pochopitel'ný, zatial' sa však zdá, že o tom pravdepodobne nad’alej rozhodovalo najmä praktické hl'adisko obchodného dopytu než prísny náboženský kontext.

Titul príspevku síce adresne smeruje k meštianskej móde, ale ako už bolo povedané, ide skôr o odraz meštianskej akceptácie medzinárodnej dobovej módy, ktorá sa aj vd’aka všeobecnému rozšíreniu grafických listov s predlohami a vzormi mohla na širokom priestore strednej Európy rýchlo unifikovat'. Nemusí teda nutne íst' o meštianske šaty, ale ide o typy oblečenia, s ktorými bola meštianska societa oboznámená, prijala ju za svoju, identifikovala sa s ňou. Hendikepy kachliarskeho remesla a jeho schopnost' verne plasticky i farebne zobrazit' námet niekedy determinovali možnosti správne ho interpretovat'. V niektorých prípadoch nebolo možné rozpoznat' určité časti odevu, formy i kachlice bývajú prepracované menej detailne. Niekedy nás to núti pochybovat' o tom, čo vidíme a niektoré časti odevov priradit' $\mathrm{k}$ viacerým možnostiam. Podobne to platí aj pri fragmentoch, kde chýba celková podoba odevu a zobrazená čast' nám aj napriek výrazným, možno až charakteristickým módnym prvkom nedovolí s istotou odev typologicky zaradit'. Napriek uvedeným nedostatkom nám kachlice a formy ponúkli pestrý prehl'ad odevov, odevných doplnkov, účesov a dokázali byt' dôstojným zdrojom informácíi i v konfrontácii s vizuálne vernejšie stvárnenými ikonografickými prameňmi.

Príspevok vznikol v rámci projektu 2/0030/15 vedeckej agentúry VEGA.

\section{Pramene a literatúra}

BRAVERMANOVÁ, M., 2006: Pohřební oděv Jana Zhořeleckého z královské hrobky v katedrále sv. Víta na Pražském hradě - Begräbnisgewand von Jan Zhořelecký aus der königlichen Gruft im Sankt-VeitsDom in der Prager Burg, AH 31, 403-412.

BRAVERMANOVÁ, M.-KOBRLOVÁ, J.-SAMOHÝLOVÁ, A., 1994: Textilie z hrobu Anny Jagellonské z Colinova mauzolea v katedrále sv. Víta na Pražském hradě - Textilien aus der Grabstätte der Anna Jagellone aus Colin-Mausoleum im Sankt-Veits-Dom in der Prager Burg, AH 19, 437-461.

Cranach the Elder, L., 1502: Portrait of Anna Cuspinian. Dostupné z: http://lucascranach.org/CH SORW_1925-1a, cit. 17. 4. 2016.

Cranach the Elder, L., 1525: Portrait of a Woman. Dostupné z: http://lucascranach.org/UK_NGL_291, cit. 17. 4. 2016.

Cranach d. Ä., L., 1530: Lucretia. Dostupné z: https://commons.wikimedia.org/wiki/File:Lucas_ Cranach_d.\%C3\%84._-_Lucretia_\%281530\%29.jpg, cit. 22. 7. 2016. 
Cranach the Younger, L., 1543: Agnes von Hayn - Staatsgalerie Stuttgart. Dostupné z: https://commons.wikimedia.org/wiki/File:Lucas_Cranach_\%28II\%29_-_Agnes_von_Hayn_-_Staatsgalerie_Stuttgart.jpg, cit. 21. 7. 2016

Dürer, A., 1490: Barbara Dürer, geb. Holper (recto) / Felslandschaft mit Drache (verso), Nürnberg GNM, Inv. Nr. Gm 1160. Dostupné z: http://duererforschung.gnm.de/index.php?id=426 \& pic_ref=tif\% $2 \mathrm{Fg}-$ m1160xrirvis_pyr_000_090 \& img_id=4168 \& pic_id=45014, cit. 20. 7. 2016.

Dürer, A., 1498: Young Couple Threatened by Death; or, the Promenade, 1498. Dostupné z: http://www. backtoclassics.com/images/pics/albrechtdurer/albrechtdurer_young_couple_threatened_by_death_or_ the_promenade.jpg, cit. 17. 4. 2016.

Dürer, A., 1498a: Self-portrait at 26 I. Dostupné z: http://www.albrecht-durer.org/Self-Portrait-at-26-I.html, cit. 17. 4. 2016.

Dürer, A., 1503/1504: The Jabach Altarpiece. Dostupné z: http://www.albrecht-durer.org/The-Jabach-Altarpiece.html, cit. 17. 4. 2016.

FAJT, J., 2003: Skulptúra a tabul'ové maliarstvo raného 16. storočia. Medzi dvorom a mestom. Maliarstvo na Spiši okolo roku 1500 a magnátska rodina Zápol'ských. In: Dejiny slovenského výtvarného umenia. Gotika (Buran, D., ed.), 399-427. Bratislava.

GEISBERG, M., von, 1909: Die Anfänge des deutschen Kupferstiches und der Meister E. S. Meister der Graphik. Band II. Leipzig.

GERÁT, I., 2013: Legendary scenes: An essay on medieval pictorial hagiography. Bratislava.

Holbein the Younger, H., 1527: Sir Thomas More. Dostupné z: http://collections.frick.org/view/objects/asitem/items\$0040:100, cit. 17. 4. 2016.

CHOVANEC, J., 1990: Odev na renesančných kachliciach z hradu Trebišov - Die Kleidung auf Renaissance-Kacheln aus der Burg Trebišov, AH 15, 385-396.

- 2005: Palatínska kachl'ová pec Imricha Perényiho. In: Gotické a renesančné kachlice v Karpatoch (Chovanec, J., ed.), 23-54, 257-259. Trebišov.

- 2005a: Grafiky nemeckých majstrov ako predlohy k renesančným kachliciam. In: Experimentálna archeológia a popularizácia archeologického bádania v múzejnej a školskej praxi. Referáty z konferencie (Kotorová-Jenčová, M., red.), 271-284. Hanušovce nad Topl'ou.

KÓNYOVÁ, A.-KÓNYA, P., 2010: Kalvínska reformácia a Reformovaná cirkev na východnom Slovensku v 16.-18. storočí. Prešov.

KOVAČEVIČOVÁ, S., 1987: Človek tvorca, pracovné motívy Slovenska vo vyobrazeniach z 9.-18. storočia. Bratislava.

KUČERA, M.-KOSTICKÝ, B., 1990: Slovensko v obrazoch. Bratislava.

KYBALOVÁ, L., 1996: Dějiny odívání. Renesance (15. a 16. století). Praha.

- 2001: Dějiny odívání. Středověk. Praha.

LOSKOTOVÁ, I.-MENOUŠKOVÁ, D.-PAVLÍK, Č.-VITANOVSKÝ, M., 2008: Krása, která hřeje. Výběrový katalog gotických a renesančních kachlů Moravy a Slezska - Schönheit, die wärmt. Gotische und renessainzeitliche kacheln aus Mähren und Schlesien (Menoušková, D.-Měřínský, Z., edd.). Uherské Hradiště.

Maler, H., 1519: Queen Anne of Hungary and Bohemia, 1519. Dostupné z: http://www.museothyssen.org/ en/thyssen/ficha obra/256, cit. 17. 4. 2016.

Metercia 2008-2011 - Šugár, M., 2008-2011: Sv. Anna Samotretia (Metercia). In: Arslexicon - výtvarné umenie na Slovensku (Balážová, B.-Pomfyová, B., edd.). Dostupné z: http://www.arslexicon.sk/?registre \& objekt=sv-anna-samotretia-metercia, cit. 14. 4. 2016.

PROCHNENKO, I.-MOJZES, V.-ŽILENKO, M., 2012: Rezul'taty issledovanija korolevskogo zamka ňalab v 2012 godu, Carpatica - Karpatyka 41, 202-249.

RUSINA, I. a kol., 2009: Renesancia. Umenie medzi neskorou gotikou a barokom. Bratislava.

RUSNÁK, R., 2009: Košice v stredoveku: na podklade archeologických výskumov. Rkp. dizertačnej práce na FF UKF v Nitre.

- 2013: Nálezy ranorenesančných foriem na kachlice z Košíc, Pamiatky a múzeá 62, č. 1, 335-353.

- 2014: Vývoj mestskej domovej parcely na príklade Mäsiarskej 57/A v Košiciach, S1Arch LXII, $315-398$.

SENDEKOVÁ, E., 2013: Ženský odev 14.-16. storočia a zbierky Šarišského múzea, Pamiatky a múzeá 62 , č. $1,61-64$.

STOLOT, F., 1981: Baltazar Behem, Kodeks Behema 1505. In: Muzea Krakowa. Muzea Świata 57. Warsaw.

STRAUSS, W., L., gen. ed., 1981: The Illustrated bartsch 9. Formely Volume 6 (Part 2). Early German Artists. Israhel Van Meckenem (Koreny, F., ed.). New York.

SUCKALE, R., 2003: Mal'by retabula hlavného oltára v Dóme sv. Alžbety v Košiciach. In: Dejiny slovenského výtvarného umenia. Gotika (Buran, D., ed.), 364-373. Bratislava. 
ŠIMČÍK, P., 2013: Záchranný archeologický výskum na obnove objektu Kováčska č. 37 v Košiciach, Východoslovenský pravek X., 225-229.

ŠIMŠA, M., 2014: Knihy krejčovských střihů v českých zemích v 16. až 18. století. Strážnice.

ŠKOVIERA, D., 2009: Renesančný humanizmus a mestá východného Slovenska. In: Rusina, I. a kol., Renesancia. Umenie medzi neskorou gotikou a barokom, 60-70. Bratislava.

ŠUGÁR, M., 2003: Neskorogotické tabul’ové maliarstvo v oblasti stredoslovenských banských miest. In: Dejiny slovenského výtvarného umenia. Gotika (Buran, D., ed.), 475-497. Bratislava.

ZUBERCOVÁ, M. M., 1988: Tisícročie módy. Z dejín odievania na Slovensku. Martin.

- 1998a: Farba a vzor v neskorostredovekej móde. In: Kováč, D. a kol., Kronika Slovenska 1. Od najstarších čias do konca 19. storočia, 187. Bratislava.

- 1998b: Podoby renesančného odevu (1). In: Kováč, D. a kol., Kronika Slovenska 1. Od najstarších čias do konca 19. storočia, 229. Bratislava.

- 2001: Košel’a ako súčast’ renesančného odevu, Pamiatky a múzeá 50, č. 4, 67-69.

ZUBERCOVÁ, M. M.-HASALOVÁ, E.-ŠIDLÍKOVÁ, Z.-VANČO, M., 2014: Móda na Slovensku. Stručné dejiny odievania. Bratislava.

\section{Zusammenfassung}

Ein Abbild der zeitgenössischen Mode des Bürgertums im 15.-16. Jahrhundert auf Kachelfunden aus Košice

Der vorliegende Beitrag wertet eine kleine Kollektion von Kacheln und Kachelformen aus Košice aus, und zwar mit der Optik der zeitgenössischen Mode so, wie sie auf ihnen dargestellt wird. Die Kollektion besteht aus vollständigen Exemplaren sowie aus kleineren Fragmenten. Es handelt sich um einen verschiedengearteten Komplex von insgesamt 16 Katalognummern, die aus archäologischen Grabungen gewonnen wurden. Das, was die Funde miteinander verbindet, ist ein zentrales figurales Thema, wobei die Motive sich unterscheiden und angefangen mit religiösen Themen über Genreszenen bis hin zu Porträts beinhalten. Die Verschiedenartigkeit der Motive ist zweitrangig, da der verbindende Rahmen und der Interessensgegenstand für uns die Kleidung der dargestellten Personen waren. Selbst wenn Kacheln für die Erforschung von zeitgenössischen Bekleidungsformen eher eine marginale Erkenntnisquelle darstellten, konnten sie doch einen bunten und authentischen Beleg für die Mode vergangener Zeiten liefern. Sie mit dieser Optik zu betrachten bedeutete, einen zeitlichen Rahmen von ungefähr hundert Jahren zu überbrücken, und zwar von der Mitte des 15. bis zur Mitte des 16. Jahrhunderts. Die hier vorgestellten Funde haben uns drei Kleidergruppen offenbart. Neben noch mittelalterlicher Kleidung tauchen auch Renaissanceelemente in der spätgotischen Mode auf, die letztendlich von der Mode der Renaissance abgelöst wurden. Im vorliegenden Beitrag haben wir versucht, die einzelnen, auf den Kachelerzeugnissen dargestellten Kleider zu beschreiben, zu identifizierten und sie typologisch und chronologisch einzuordnen sowie Analogien für sie zu finden, vornehmlich in den visuell treueren Darstellungen von ikonographischen Quellen wie etwa Altarbilder oder zeitgenössische Porträts es sind. Die Handicaps des Hafnerhandwerks und seine Fähigkeit, ein Thema plastisch und auch farblich getreu wiederzugeben, haben die Möglichkeiten einer richtigen Interpretation bisweilen determiniert. In einigen Fällen war es unmöglich, gewisse Bekleidungsteile zu erkennen, Formen und auch Kacheln sind für gewöhnlich weniger detailliert ausgearbeitet. Dies zwang uns manchmal dazu, daran zu zweifeln, was wir sehen und einige Bekleidungsteile mehreren Möglichkeiten zuzuordnen. Dies hatte auf ähnliche Weise auch bei den Fragmenten Gültigkeit, etwa wenn das vollständige Aussehen einer Kleidung fehlte und der dargestellte Teil uns auch trotz eines markanten, womöglich gar charakteristischen modischen Elements es nicht mit Sicherheit erlaubte, eine Kleidung typologisch einzuordnen. Trotz der hier genannten Unzulänglichkeiten haben uns die Kacheln und Kachelformen eine bunte Übersicht von Kleidern, Kleideraccessoires sowie Frisuren geboten und es geschafft, eine würdige Informationsquelle zu sein. 
Für die Bestimmung der einzelnen Kleidertypen und ihre chronologische Einordnung hat immer nur allein die Primärquelle, d.h. der Fund selbst gedient. Grund dafür ist selbstverständlich auch der Umstand, dass bloß ein Minimum an Funden eine identifizierte ikonographische Vorlage besitzt. Der ausgewertete Fundkomplex enthält bislang bloß drei Fragmente von Kachelformen, deren graphische Vorlagen wir erkennen. Zwei von ihnen wurden früher bereits von J. Chovanec identifiziert (2005a), eine konnte während der Ausarbeitung des vorliegenden Beitrags identifiziert werden. Dabei handelt es sich um eine deutsche Grafikvorlage des Meisters E. S., bzw. um Ishrael von Meckenem und um den Meister H. S. Da die Funde der Kachelformen aus Košice und der Kacheln aus Trebišov eine mögiche genetische Verbundenheit zwischen Werkstatt und Erzeugnis andeuten, beziehen wir uns im vorliegenden Beitrag an mehreren Stellen auf diese Kollektion. Besonders wenn uns vollständig erhaltene Kachelexemplare von der Trebišover Burgruine Parič dabei halfen, durch die Bruchstückhaftigkeit der Funde aus Košice verursachte Unzulänglichkeiten zu überbrücken. Da wir wissen, dass die Ikonographie der Themen oftmals aus verschiedenen zeitgenössischen Grafikvorlagen übernommen wurde, ist es nicht möglich, eine regionale oder soziale Ausschließlichkeit der dargestellten Kleider hervorzuheben. Es ist eher ein Beleg dafür, dass das Bürgertum in unserer Umgebung die internationale Mode jener Zeit übernommen hat, und die dargestellten Szenen für uns deshalb nicht an Authentizität verlieren. Das Vordringen neuer Elemente der Mode und die nachhaltige Beliebtheit der älteren waren langfristige und langsam ablaufende Prozesse, die parallel nebeneinander existierten, wobei die unterschiedlichen Sozietäten unterschiedlich sensibel auf sie reagierten. Auch das Material, das manchmal auf einem Artefakt die Verwendung eines scheinbaren Anachronismus neben progressiven Elementen offenbart, hilft uns dabei einen Einblick in sie zu bekommen und sie besser zu verstehen. Ob eine Kleidung der auf den Kacheln dargestellten Personen im Einklang mit der aktuellen Mode war, hing mehr von der konkreten Vorliebe des Auftraggebers, der Auswahl der Motive und dem Angebot der Werkstatt ab. Der Titel des vorgelegten Beitrags ist zwar gezielt auf die Mode des Bürgertums ausgerichtet, jedoch geht es, wie bereits gesagt, eher um ein Abbild der bürgerlichen Akzeptanz der internationalen Mode jener Zeit, die sich auch dank der allgemeinen Verbreitung von Grafikblättern mit den Vorlagen und Vorbildern in dem breiten Raum Mitteleuropas schnell vereinheitlichen konnte. Es musste sich demnach nicht zwangsläufig um Kleidung des Bürgertums handeln, sondern um Bekleidungstypen, mit denen die bürgerliche Sozietät vertraut war, die sie übernommen und sich mit ihr identifiziert hat.

Der vorliegende Beitrag entstand im Rahmen des Projekts 2/0030/15 der Wissenschaftsagentur VEGA.

Mgr. Lucia Luštíková, PhD., Archeologický ústav SAV - OVVS Košice, Hrnčiarska 13, SK 04001 Košice, Slovenská republika,lustikova@saske.sk

Mgr. Rastislav Rusnák, PhD., Fakulta umení Technickej univerzity v Košiciach, Katedra teórie a dejín umenia, Watsonova 4, SK 04200 Košice, Slovenská republika, rastislav.rusnak@hotmail.sk 
